\title{
Double-Edged Sword of Global Financial Crisis and COVID-19 Pandemic on Crude Oil Stock Returns
}

\author{
Monday Osagie Adenomon \\ Department of Statistics \& NSUK-LISA Stat Lab, Nasarawa State University, Keffi, \\ Nigeria \\ Corresponding Author: Email address: adenomonmo@nsuk.edu.ng
}

Ngozi G. Emenogu

Department of Statistics, Federal Polytechnic, Bida, Nigeria

Email address: ngelive4jesus@gmail.com

\begin{abstract}
This study investigates the impact of global financial crisis and the present COVID-19 pandemic on daily and weekly Crude oil futures using four variants of ARMA-GARCH models: ARMAsGARCH, ARMA-eGARCH, ARMA-TGARCH and ARMA- aPARCH with dummy variables We also investigated the persistence, half-life and backtesting of the models. This study therefore seeks to contribute to the body of literature on the impact of global financial crisis and the present COVID-19 pandemic on crude oil futures market. This investigation of the impact of global financial crisis and the COVID-19 on crude oil futures has not been much studied at present. We obtained and analyzed the daily and weekly crude oil futures from secondary sources. Daily crude oil futures used in this study covers the period from the $4^{\text {th }}$ January 2000 to $27^{\text {th }}$ April 2020 while the weekly crude oil futures covered from $2^{\text {nd }}$ January 2000 to $26^{\text {th }}$ April 2020 . The global financial crisis period covered from $2^{\text {nd }}$ July 2007 to $31^{\text {st }}$ March 2009 and the current COVID-19 pandemic covered from $1^{\text {st }}$ January 2020 to $27^{\text {th }}$ April, 2020. The study used both student $t$ and skewed student $t$ innovations with AIC, goodness-of-test fit and backtesting to select the best model. Most of the estimated ARMA-GARCH models are supported by skewed student $t$ distribution while most of the ARMA-GARCH models exhibited high persistence values in the presence of global financial crisis and the COVID-19 pandemic. In the overall, the estimated ARMA(1,0)-eGARCH(2,1) and ARMA(1,0)-eGARCH(2,2) model for daily crude oil futures and weekly crude oil futures respectively have been significantly impacted by the global financial crisis and the Present COVID-19 pandemic while the preferred estimated models also passed the goodness-of-test fit and backtesting.This study recommends shareholders and investors should think outside the box as crude oil futures tend to be affected by global financial crisis and COVID-19 pandemic while countries also that depend mostly on crude oil are encouraged to diversify their economy in other to survive and be sustained during financial and health crisis.
\end{abstract}

Keywords: Crude oil, Global financial crisis, COVID-19, Stock, Returns, Persistence.

JEL Classification: C22, C51, C32, D53, E32 


\section{Introduction}

Today, the world is battling COVID-19, also known as coronavirus pandemic. The outbreak of this virus was first noticed in Wuhan, China in December 2019. The World Health Organization (WHO) declared it a "public health emergency of international concern" on 30 January, 2020, and finally, on 11 March, 2020, WHO declared the coronavirus outbreak a pandemic (Wikipedia, (2020). The virus, which, according to WHO, is highly contagious and spreads very fast, has spread to over two hundred (200) countries, has infected over four million seven hundred and thirty-one thousand, four hundred and fifty-eight $(4,731,458)$ people globally, has also resulted in over three hundred and sixteen thousand, one hundred and sixty-nine $(316,169)$ fatalities globally (WHO, 2020). It therefore poses a very serious health challenge.

In addition to its serious implications for people's health, COVID-19 is also impacting businesses and economy significantly. This is supported by Adrian \&Natalucci (2020) in opining that necessary measures taken to contain the spread of the virus have resulted in economic downturn, and with financial system being adversely impacted. But whether it will lead to financial crisis, (Kenton, reviewed by Scott, 2020) opines that though it is too early to tally up the total cost of the coronavirus pandemic, there is sign of worldwide supply interruption, heightened volatility and steep losses in financial markets, all of which are a warning for financial crisis.

Global financial crisis is financial crisis that affects many countries of the world at the same time. Financial crisis can be defined as any of the very many situations in which values of some financial assets suddenly nosedive, businesses and consumers become unable to pay their bills, and financial institutions experience liquidity shortages, (Kenton, reviewed by Scott, 2020). The current global financial crisis is being exacerbated by COVID-19 which necessitated lockdown of cities and businesses the world over, which impacts crude oil market with the price of oil steeping terribly.

Crude oil price is presently in steep decline, this is because crude oil, being a commodity, the price tends to fluctuate with larger fluctuations than more stable investments such as stocks and bonds (Lioudis, 2020). It listed some of the causes of crude oil price fluctuation to include OPEC decisions, laws of demand and supply, natural disaster, and political unrest affecting large oil producing nation(s). COVID-19 pandemic is a disaster which impact on crude oil prices is enormous and devastating.

Efforts to study the relationship between crude oil prices and the stock returns in the industry have yielded different results: for instance, whereas Sari \&Soytas (2006) found that oil price shocks do not have a significant impact on real stock returns in the Istanbul Stock Exchange, Adekunle, et.al (2020) studying the nexus between crude oil prices and stock returns of nine major oil and gas companies currently listed on the Nigerian Stock Exchange, using data that span over the period of January 2014 to November 2019, found that oil price matters in the predictability of stock returns for some listed oil and gas companies in Nigeria. However, other factors that can affect stock prices, according to Hall (2019) include interest rate, saying that there is inverse relationship between interest rate and stock price; and Ramsharan (2019) submits that financial crisis affects stock value adversely.

This paper studies the double-edged sword effect of global financial crisis and covid-19 pandemic on crude oil stock returns, which in effect aims to study if crude oil prices have been 
impacted by financial crisis and health crisis. And to achieve this, volatility modeling of financial time series will be explored.

In the last few years, modeling and forecasting volatility of a financial time series has attracted a lot of interest of researchers; mainly because volatility, which is a statistical measure of dispersion of returns of a given security or market index, is taken as an important concept for many economic and financial applications such as portfolio and risk management and pricing of assets (Arum \&Uche, 2017; Emenogu, et.al, 2020). Emenogu, et.al (2020) further states that volatility can be measured by either standard deviation or variance between returns of the same security or market index, and opined that the higher the volatility of an asset return, the riskier the security. Crude oil prices fluctuate heavily in global market and its stock prices or returns are also highly volatile (Ulusoy\&Ozdurak, 2018). The high risk in investment in oil security and the high volatility of oil stock returns does not discourage investors from investing in the stock of oil companies; believing that the higher the risk, the higher the return.

In studying the volatility of oil stock returns occasioned by the fluctuations in crude oil prices resulting from the current global financial crisis and covid-19 pandemic, this study uses the combination of autoregressive moving average (ARMA) models, a popular and excellent model for modeling and forecasting univariate time series data (Emenogu, et.al, 2019) proposed by Box \& Jenkins (1970), and generalized autoregressive conditional heteroscedasticity (GARCH) family models. The flexibility and simplicity of the ARMA model, combined with the capacity of the GARCH models to capture volatility in financial time series, to yield the ARMA-GARCH models (Emenogu, et.al, 2019). The advantage of this combination is its flexibility and tractability in allowing the model to capture both the mean and the variance components in the financial time series volatility (Lange, 2011; Panait\&Slavescu, 2012), thus yielding a more reliable estimates for decision making.

\section{Literature reviews}

Crude oil futures stock prices and returns have attracted many researchers to study the effect of wars, financial crisis on the performance of the market in such periods. This section provides brief literature reviews in that regards.

Bencivenga et al. (2012) investigated crude oil volatility and its relationships with Dollar/Euro exchange rate, US interest rate, the crude oil futures open interest, US oil imports and gold price over the period of 1993 to 2009 . The study revealed one long run relationship equation and the authors found that exchange rate and gold price played dominant role in the estimated model.

Zavadska et al. (2020) investigated Bent crude oil and futures prices using GARCH type models during first gulf war 1990/91, Asian financial crisis 1997/98, the US terrorist attack 2001 and global financial crisis 2008/2009. The authors found that higher level of volatility during crisis was associated with oil supply and demand disruptions while higher volatility persistence associated with financial and economic crises.

Singh and Singh (2017) examined the impact of financial crisis on the volatility of crude oil market in India. The study revealed no evidence of structural break was found except for 
CUSUM of squares test. Evidence from EGARCH model with dummy, the study found that there was no effect of global financial crisis on the volatility of crude spot market of India.

Chen (2014) investigated the fear spillovers between for implied volatility indices which include MVX in Canada, VXJ in Japan, VDAX in Germany and VIX in the United States using a Copula-based bivariate Markov-switching model. They found that there exist linkages between implied volatility indices and are more evident when the indices rise.

Yousef (2020) investigated the impact of Coronavirus on stock market volatility in United States using three stock market indexes (S\&P500, Dov Jones and Nasdaq). The study employed GARCH, TGARCH and GJR-GARCH models with COVID-19 as dummy variable. The results revealed in the condiational variance equation that COVID-19 had a significant positive impact on all the three stock indexes, implying that COVID-19 had increased market volatility.

Wei and Wei (2019) investigated the long-term connection between crude oil futures market and China stock market across financial crises with the use of non-linear threshold cointegration method. The study revealed exchange rate market as a key factor in transferring the impact of oil price on China stock market after the financial crisis.

Junttila and Raatikainen (2018) used daily data from 1989 to 2016 to investigate the correlations between gold and oil market futures and equity returns in the aggregate US equities increased in crisis period while gold futures became negatively correlated with US equities around times of financial crises.

Zhang and Wang (2013) investigated the price discovery and risk transfer functions in the crude oil and gasoline futures market. The authors found financial crisis has not significantly influenced the price discovery and risk transfer functions between crude oil and gasoline futures markets.

Kang and Yoon (2017) examined the dynamic spillover effects among crude oil, precious metal, and agricultural commodity futures markets using multivariate DECO-GARCH model and spillover index. The study revealed a positive equicorrelation between commodity futures market return increased shaply during financial crises period.

Jiang and Zhou (2014) investigated the weak-form efficient of the WTI crude oil futures market. They found that market is inefficient after turbulent and crises event occurred such as oil crash in 1985, the Gulf war and the oil price crash in 2008.

Luo et al. (2020) introduced the Infinite Hidden Markov (IHM) model to forecast crude oil realized volatility in the presence of structural breaks such as change in policy, exogenous shock and other factors like financial and health crisis. The authors recommended that IHM-HAR models with exogenous factors are superior for short term forecast and provides economic gains.

Adenomon et al. (2020) examined the effect of COVID-19 outbreak on the performance of the Nigeria stock exchange using historical data covering $2^{\text {nd }}$ March 2015 to $16^{\text {th }}$ April, 2020 sourced from a secondary source. The authors applied Quadratic GARCH (QGARCH) and Exponential GARCH (EGARCH) models with dummy variable were applied to the stock returns and the results shown that the COVID-19 has had negative effect on the stock returns in Nigeria. 
From the foregoing, crude oil futures have not be study especially with the impact of the global financial crisis and the present COVID-19 pandemic. Hence the reason for this present study.

\section{Methodology}

This study uses GARCH and ARMA models in data analysis in order to select the model or models that give the best possible forecast. Particularly, the combination of the GARCH and ARMA models, the so called ARMA-GARCH models come very handy here due to their robustness for forecasting the volatility of financial time series data, and because of their superiority in modelling the conditional mean and conditional variance (volatility) of any financial time series(Ruppert, 2011).So we present in this section ARMA-GARCH models and some of their extensions.

\section{The ARMA-GARCH Model}

The ARMA (p,q)-GARCH $(1,1)$ model can be specified as follows:

$$
\left.\begin{array}{l}
r_{t}=\sum_{i=1}^{p} \theta_{i} r_{t-i}+\sum_{j}^{q} \phi_{j} \varepsilon_{t-j}+\varepsilon_{t} \\
\varepsilon_{t} \sqrt{\sigma_{t}^{2} Z_{t}}, \quad Z_{t} \sim \mathrm{D}\left(0, \sigma_{\mathrm{t}}^{2}\right) \\
\sigma_{\mathrm{t}}^{2}=\omega+\alpha_{1} \varepsilon_{\mathrm{t}-1}^{2}+\beta_{1} \sigma_{\mathrm{t}-1}^{2}
\end{array}\right\}
$$

where $r_{t}$ is the daily rate of return, $\theta$ is the $\operatorname{AR}(p)$ term in the mean equation in order to account for time dependence in returns, $\phi$ is the MA(q) term in the mean equation, $\varepsilon_{t}$ is the residual term in the mean equation, $\mathrm{Z}_{\mathrm{t}}$ is the standardized residual sequence of iid random variable with mean zero and variance as one while $\mathrm{D}$ represents distribution of the shock returns (Moshiri and Foroutan, 2006; Chen et al., 2013; Meitz and Saikkonen, 2011; Francq and Zakoian, 2004; Ling and McAleer, 2003; Koul and Ling, 2006; Zhu and Ling, 2011).

\section{ARCH Model}

Autoregressive Conditional Heteroskedasticity (ARCH) Family Model or Generalized Autoregressive Conditional Heteroskedasticity (GARCH) Family Model, according to Atoi (2014), requires two distinct specifications, namely: the mean and the variance equations. The mean equation for a conditional heteroskedasticity in a return series, $y_{t}$ is given by

$$
y_{t}=E_{t-1}\left(y_{t}\right)+\varepsilon_{t}
$$

where

$$
\varepsilon_{t}=\phi_{t} \sigma_{t}
$$

The mean equation in equation (2) also applies to other GARCH family models. $E_{t-1}($.$) is the$ expected value conditional on information available at time $t$ - 1 , while $\varepsilon_{t}$ is the error generated from the mean equation at time $\mathrm{t}$ and $\phi_{t}$ is the sequence of independent and identically distributed random variables with zero mean and unit variance.

The variance equation for an $\mathrm{ARCH}(\mathrm{p})$ model is given by 


$$
\sigma_{t}^{2}=\omega+\alpha_{1} a_{t-1}^{2}+\ldots+\alpha_{p} a_{t-p}^{2}
$$

The equation reveals that large values of the innovation of asset returns have bigger impact on the conditional variance because they are squared, meaning that a large shock tends to follow another large shock and that is the same way the clusters of the volatility behave. So the $\mathrm{ARCH}(\mathrm{p})$ model becomes:

$$
a_{t}=\sigma_{t} \varepsilon_{t}, \quad \sigma_{t}^{2}=\omega+\alpha_{1} a_{t-1}^{2}+\ldots+\alpha_{p} a_{t-p}^{2}
$$

Where $\varepsilon_{t} \sim N(0,1)$ iid, $\omega>0$ and $\alpha_{i} \geq 0$ for $i>0$. In practice, $\varepsilon_{t}$ is assumed to follow the standard normal or a standardized student $t$ distribution or a generalized error distribution (Tsay 2005).

\section{Asymmetric Power ARCH}

Rossi (2004) asserts that the asymmetric power ARCH model below, which was proposed by Ding, Engle \& Granger (1993) forms the basis for deriving the GARCH family models Given that:

$$
\begin{gathered}
r=\mu+a_{t}, \\
\varepsilon_{t}=\sigma_{t} \varepsilon_{t}, \\
\varepsilon_{t} \sim N(0,1) \\
\sigma_{t}^{\delta}=\omega+\sum_{i=1}^{p} \alpha_{i}\left(\left|a_{t-i}\right|-\gamma_{i} a_{t-i}\right)^{\delta}+\sum_{j=1}^{q} \beta_{j} \sigma_{t-j}^{\delta},
\end{gathered}
$$

where

$$
\begin{array}{ll}
\omega>0, & \delta \geq 0, \\
\alpha_{i} \geq 0 & i=1,2, \ldots, p \\
-1<\gamma_{i}<1 & i=1,2, \ldots, p \\
\beta_{j}>0 & j=1,2, \ldots, q
\end{array}
$$

This model is known to impose a Box-Cox transformation of the conditional standard deviation process and the asymmetric absolute residuals. The leverage effect is the asymmetric response of volatility to positive and negative "shocks".

Standard GARCH(p, q) Model:

The mathematical model for the $\operatorname{sGARCH}(\mathrm{p}, \mathrm{q})$ model is obtained from equation (5) by letting $\delta=2$ and $\gamma_{i}=0, i=1, \ldots, p$ to be:

$$
a_{t}=\sigma_{t} \varepsilon_{t}, \quad \sigma_{t}^{2}=\omega+\sum_{i=1}^{p} \alpha_{i} a_{t-i}^{2}+\sum_{j=1}^{q} \beta_{j} \sigma_{t-j}^{2}
$$

Where $a_{t}=r_{t}-\mu_{t}\left(r_{t}\right.$ is the continuously compounded log return series), and 
$\varepsilon_{t} \sim N(0,1)$ iid , the parameter $\alpha_{i}$ is the ARCH parameter and $\beta_{j}$ is the GARCH parameter, and $\omega>0, \alpha_{i} \geq 0, \beta_{j} \geq 0$, and $\sum_{i=1}^{\max (p, q)}\left(\alpha_{i}+\beta_{i}\right)<1$, (Rossi, 2004; Tsay, 2005 and Jiang, 2012).

The restriction on $\mathrm{ARCH}$ and GARCH parameters $\left(\alpha_{i}, \beta_{j}\right)$ suggests that the volatility $\left(a_{i}\right)$ is finite and that the conditional standard deviation $\left(\sigma_{i}\right)$ increases. It can be observed that if $\mathrm{q}=0$, then the model GARCH parameter $\left(\beta_{j}\right)$ becomes extinct and what is left is an ARCH(p) model. To expatiate on the properties of GARCH models, the following representation is necessary: Let $\eta_{t}=a_{t}^{2}-\sigma_{t}^{2}$ so that $\sigma_{t}^{2}=a_{t}^{2}-\eta_{t}$. By substituting $\sigma_{t-i}^{2}=a_{t-i}^{2}-\eta_{t-i},(i=0, \ldots, q)$ into Eq. (4), the GARCH model can be rewritten as

$$
a_{t}=\alpha_{0}+\sum_{i=1}^{\max (p, q)}\left(\alpha_{i}+\beta_{i}\right) a_{t-i}^{2}+\eta_{t}-\sum_{j=1}^{q} \beta_{j} \eta_{t-j},
$$

It can be seen that $\left\{\eta_{t}\right\}$ is a martingale difference series (i.e., $E\left(\eta_{t}\right)=0$ and $\operatorname{cov}\left(\eta_{t}, \eta_{t-j}\right)=0$, for $\left.j \geq 1\right)$. However, $\left\{\eta_{t}\right\}$ in general is not an iid sequence.

A GARCH model can be regarded as an application of the ARMA idea to the squared series $a_{t}^{2}$. Using the unconditional mean of an ARMA model, results in this

$$
\mathrm{E}\left(a_{t}^{2}\right)=\frac{\alpha_{0}}{1-\sum_{i=1}^{\max (p, q)}\left(\alpha_{i}+\beta_{i}\right)}
$$

provided that the denominator of the prior fraction is positive. (Tsay, 2005)

When $\mathrm{p}=1$ and $\mathrm{q}=1$, we have $\operatorname{GARCH}(1,1)$ model given by:

$$
\begin{aligned}
& a_{t}=\sigma_{t} \varepsilon_{t}, \\
& \sigma_{t}^{2}=\omega+\alpha_{1} a_{t-1}^{2}+\beta_{1} \sigma_{t-1}^{2},
\end{aligned}
$$

\section{EGARCH Model}

The Exponential Generalized Autoregressive Conditional Heteroskedasticity (EGARCH) Model proposed by Nelson (1991), Enocksson and Skoog(2012) pointed out, was to overcome some weaknesses of the GARCH model in handling financial time series, in particular, to allow for asymmetric effects between positive and negative asset returns, he considered the weighted innovation

$$
g\left(\varepsilon_{t}\right)=\theta \varepsilon_{t}+\gamma\left[\left|\varepsilon_{t}\right|-E\left(\left|\varepsilon_{t}\right|\right)\right]
$$

where $\theta$ and $\gamma$ are real constants. Both $\varepsilon_{t}$ and $\left|\varepsilon_{t}\right|-E\left(\left|\varepsilon_{t}\right|\right)$ are zero-mean iid sequences with continuous distributions. Therefore, $E\left[g\left(\varepsilon_{t}\right)\right]=0$. The asymmetry of $g\left(\varepsilon_{t}\right)$ can easily be seen by rewriting it as

$$
g\left(\varepsilon_{t}\right)=\left\{\begin{array}{l}
(\theta+\gamma) \varepsilon_{t}-\gamma E\left(\left|\varepsilon_{t}\right|\right) \text { if } \varepsilon_{t} \geq 0, \\
(\theta-\gamma) \varepsilon_{t}-\gamma E\left(\left|\varepsilon_{t}\right|\right) \text { if } \varepsilon_{t}<0 .
\end{array}\right.
$$


An EGARCH( $m, s)$ model, according to Tsay (2005), Dhamija and Bhalla (2010), Jiang (2012), Ali (2013) and Grek (2014), can be written as

$$
a_{t}=\sigma_{t} \varepsilon_{t}, \quad \ln \left(\sigma_{t}^{2}\right)=\omega+\sum_{i=1}^{s} \alpha_{i} \frac{\left|a_{t-i}\right|+\theta_{i} a_{t-i}}{\sigma_{t-i}}+\sum_{j=1}^{m} \beta_{j} \ln \left(\sigma_{t-i}^{2}\right),
$$

Which specifically results in $\operatorname{EGARCH}(1,1)$ being written as

$$
\begin{gathered}
a_{t}=\sigma_{t} \varepsilon_{t} \\
\ln \left(\sigma_{t}^{2}\right)=\omega+\alpha\left(\left[\left|a_{t-1}\right|-E\left(\left|a_{t-1}\right|\right)\right]\right)+\theta a_{t-1}+\beta \ln \left(\sigma_{t-1}^{2}\right)
\end{gathered}
$$

where $\left|a_{t-1}\right|-E\left(\left|a_{t-1}\right|\right)$ are iid and have mean zero. When the EGARCH model has a Gaussian distribution of error term, then $E\left(\left|\varepsilon_{t}\right|\right)=\sqrt{2 / \pi}$, which gives:

$$
\ln \left(\sigma_{t}^{2}\right)=\omega+\alpha\left(|| a_{t-1} \mid-\sqrt{2 / \pi}\right)+\theta a_{t-1}+\beta \ln \left(\sigma_{t-1}^{2}\right)
$$

$\operatorname{TGARCH}(\mathbf{p}, \mathbf{q})$ Model

TGARCH model stands for Threshold GARCH model, and it is another model used to handle leverage effects. The TGARCH(p, q) model is given as follows:

$$
\sigma_{t}^{2}=\alpha_{0}+\sum_{i=1}^{p}\left(\alpha_{i}+\gamma_{i} N_{t=i}\right) a_{t-i}^{2}+\sum_{j=1}^{q} \beta_{j} \sigma_{t-j}^{2},
$$

where $N_{t-i}$ is an indicator for negative $a_{t-i}$, that is,

$$
N_{t-i}=\left\{\begin{array}{l}
1 \text { if } a_{t-i}<0 \\
0 \text { if } a_{t-i} \geq 0
\end{array}\right.
$$

and $\alpha_{i}, \gamma_{i}$, and $\beta_{j}$ are nonnegative parameters satisfying conditions similar to those of GARCH models, (Tsay, 2005). When $p=1, q=1$, the TGARCH(1,1) model becomes:

$$
\sigma_{t}^{2}=\omega+\left(\alpha+\not N_{t-1}\right) a_{t-1}^{2}+\beta \sigma_{t-1}^{2}
$$

\section{Persistence and Half-life Volatility}

The persistence of a GARCH model can be calculated as the sum of GARCH ( $\left.\beta_{1}\right)$ and ARCH ( $\alpha_{1}$ ) coefficients that is $\alpha+\beta_{1}$ (Ahmed et al, 2018).

The mathematical expression of half-life volatility is given as

$$
\text { Half }- \text { Life }=\frac{\ln (0.5)}{\ln \left(\alpha_{1}+\beta_{2}\right)}
$$

It can be noted that the value of $\alpha+\beta_{1}$ influences the mean reverting speed as shown in Ahmed et al., 2018).

\section{ARCH-LM}

The Autoregressive Conditional Heteroscedasticity-Lagrange Multiplier (ARCH-LM) test proposed by Engle's (1982) for testing autoregressive conditional heteroscedasticity is the undisputed and most commonly applied standard test for detecting the presence of ARCH effect 
(Sjölander, 2011). The test circumvents the problem of high dimensionality in multivariate tests for ARCH in (VAR) models (Catani \&Ahlgren, 2017), and Tsay (2005) says that it is one of two tests available for detecting $\mathrm{ARCH}$ effect in the residual of a mean equation, the other method being the usual Ljung-Box statistic, $\mathrm{Q}(\mathrm{m})$.

If we let $e_{t}=r_{t}-\mu_{t}$ be the residuals of the mean equation, the test is equivalent to the usual $F$ statistic for testing the hypothesis that there is ARCH effect;

$\mathrm{H}_{0}: \alpha_{i}=0,(i=1,2, \cdots, p)$ in the linear regression:

$$
\begin{aligned}
& e_{t}^{2}=\alpha_{0}+\sum_{i=1}^{p} \alpha_{i} e_{t}^{2}+\delta_{t} \\
& \text { or } e_{t}^{2}=\alpha_{0}+\alpha_{1} e_{t-1}^{2}+\cdots+\alpha_{p} e_{t-p}^{2}+\delta_{t} ; t=p+1, \cdots, T
\end{aligned}
$$

where,

$\delta_{t}$ is the error term, $p$ is a prespecified positive integer, and $T$ is the sample size. (Tsay, 2005; Sjölander, 2011)

Now, let

$\operatorname{SSR}_{0}=\sum_{t=p+1}^{T}\left(a_{t}^{2}-\bar{\omega}\right)^{2}$,

where

$\bar{\omega}=\frac{1}{T} \sum_{t=1}^{T} e_{t}^{2}$ is the sample mean of $e_{t}^{2}$,

and $S S R_{1}=\sum_{t=p+1}^{T} \hat{\delta}_{t}^{2}$

where

$\hat{\delta}_{t}$ is the $k$ regression.

Thus the test statistic is $F=\frac{\left(S S R_{0}-S S R_{1}\right) / p}{S S R_{1} /(T-2 p-1)}$,

which is asymptotically chi-squared distribution with $p$ degrees of freedom ; that is $\chi^{2}(p)$ under $\mathrm{H}_{0}$, and the decision rule is to reject $\mathrm{H}_{0}$ if $F>\chi_{p(\alpha)}^{2}$, if the p-value of $\mathrm{F}$ is less than $\alpha$ (Tsay, 2005).

\section{Materials and Methods}

The data used in this study were collected from www.investing.com. The study used daily and weekly crude oil futures stock prices. Daily crude oil futures used in this study covers the period from the $4^{\text {th }}$ January 2000 to $27^{\text {th }}$ April 2020 while the weekly crude oil futures covered from $2^{\text {nd }}$ January 2000 to $26^{\text {th }}$ April 2020 . The global financial crisis period covered from $2^{\text {nd }}$ July 2007 to $31^{\text {st }}$ March 2009 as defined by Reserve Bank of Australia (2020). While the current COVID19 pandemic covered from $1^{\text {st }}$ January 2020 to $27^{\text {th }}$ April, 2020. The global financial crisis 
(GFC) and the COVID-19 pandemic crisis were represented as dummy variable. For global financial crisis dummy, 0 represents pre and post global financial crisis while 1 represents the global financial crisis period. For COVID-19, 0 represents pre COVID-19 period while 1 represents the COVID-19 pandemic period.

The returns were calculated using the following formula:

$$
R_{t}=\ln P_{t}-\ln P_{t-1}
$$

where $R_{t}$ is return at time $\mathrm{t}$; ln is the natural logarithm; $P_{t}$ is the current stock price at time $\mathrm{t}$, and $P_{t-1}$ is the previous stock price at time $t-1$.

\section{Descriptive Statistics}

Table 1: Data Summary for Daily Crude Oil WTI Futures Historical Stock Prices and Returns

\begin{tabular}{|l|l|c|c|c|r|r|r|}
\hline Variables & Mean & Max. & Min. & SD & Skewness & Kurtosis & JB \\
\hline \multicolumn{7}{|c|}{ Daily Oil Futures Stock Price (Full Sample)(01/04/2000-04/27/2020); T= 5177 } \\
\hline Price & 61.57540 & 145.2900 & 10.01000 & 26.10510 & 0.398003 & 2.327552 & $\mathbf{2 3 4 . 2 1 8 8}$ \\
\hline Daily Oil Futures Stock Price (Full Sample)(01/04/2000-04/27/2020); T=5177 \\
\hline Log(Price) & 4.022398 & 4.978730 & 2.303580 & 0.456812 & -0.336204 & 2.237315 & $\mathbf{2 2 3 . 0 0 3 6}$ \\
\hline \multicolumn{7}{|c|}{ Changes in Prices (Log-Returns)(01/04/2000-04/27/2020); T=5176 } \\
\hline Returns & -0.000134 & 0.319640 & -0.601680 & 0.027099 & -2.290925 & 63.80617 & $\mathbf{8 0 1 9 3 1 . 4}$ \\
\hline
\end{tabular}

In bold significant Jarque-Bera (JB) test at $5 \%$ level of significance.

The table 1 presents the descriptive statistics of the daily crude oil futures price from the $4^{\text {th }}$ January 2000 to $27^{\text {th }}$ April 2020. the maximum stock price for Crude oil futures was $\$ 145.2900$ that occurred during the global financial crisis and the minimum stock price for the crude oil futures was $\$ 10.01000$ which occurred during the COVID-19 crisis. The price had high standard deviation with positive skewness with a moderate kurtosis but the stock price was not normally distributed using Jarque-Bera (JB) statistic. The log stock price revealed an average of 4.022398, maximum value of 4.978730, minimum value of 2.303580 with standard deviation of 0.456812 , having a negative skewness but have a similar value of kurtosis as the stock price of the crude oil futures and the $\log$ price series was not normally distributed. The log returns of crude oil futures exhibited a negative mean (-0.000134) which signifies a loss in stock returns over the period 
under consideration. In addition, 0.319640 was maximum returns, -0.601680 was minimum returns with standard deviation of 0.027099 , but the returns exhibited negative skewness and very high kurtosis value of 63.80617 and finally, the returns series was not normally distributed and there is evidence of arch effects in the returns series.

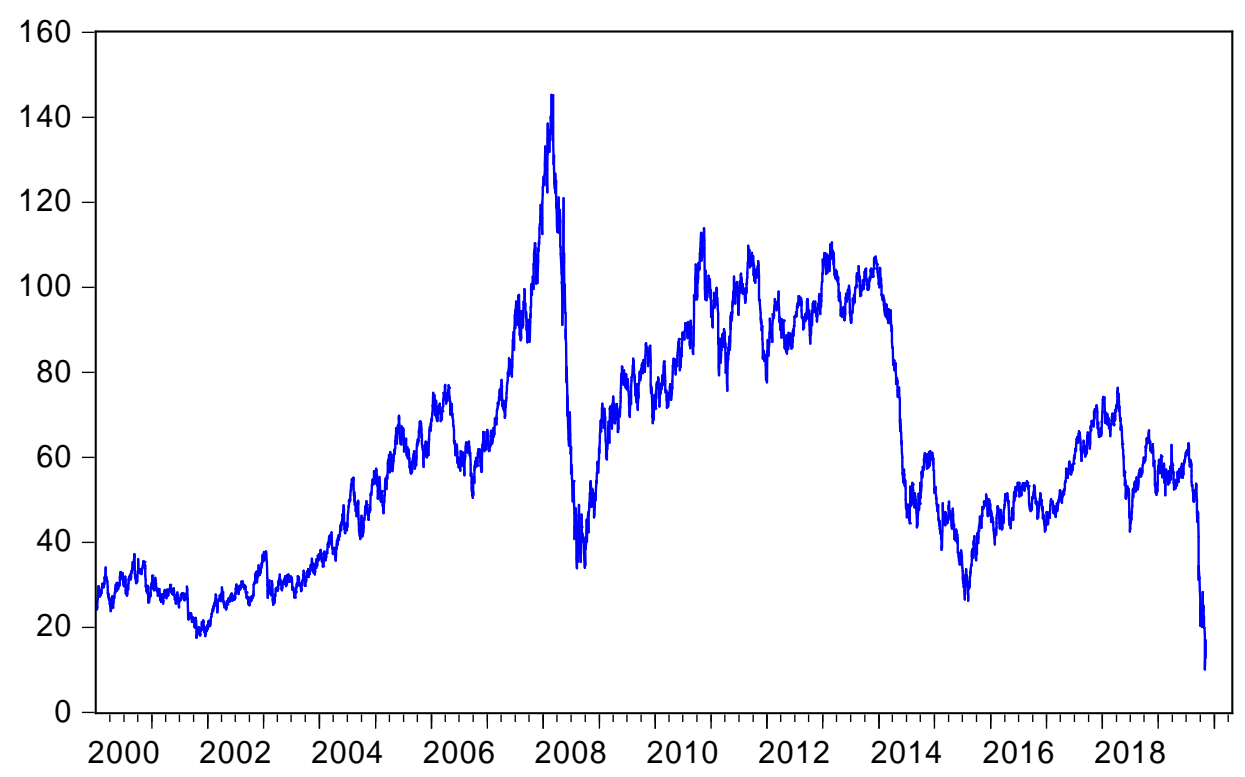

Fig. 1: Time plot of Daily Crude Oil WTI Futures Historical Stock Prices from $4^{\text {th }}$ January 2000 to $27^{\text {th }}$ April 2020

Fig. 1 represented the time plot of the daily crude oil futures stock prices. The highest stock price occurred during the global financial crisis of mid 2007 and early 2009 but the least stock price occurred during the COVID-19 crisis which indicated that crude oil futures was worse hit by the COVID-19 pandemic. 


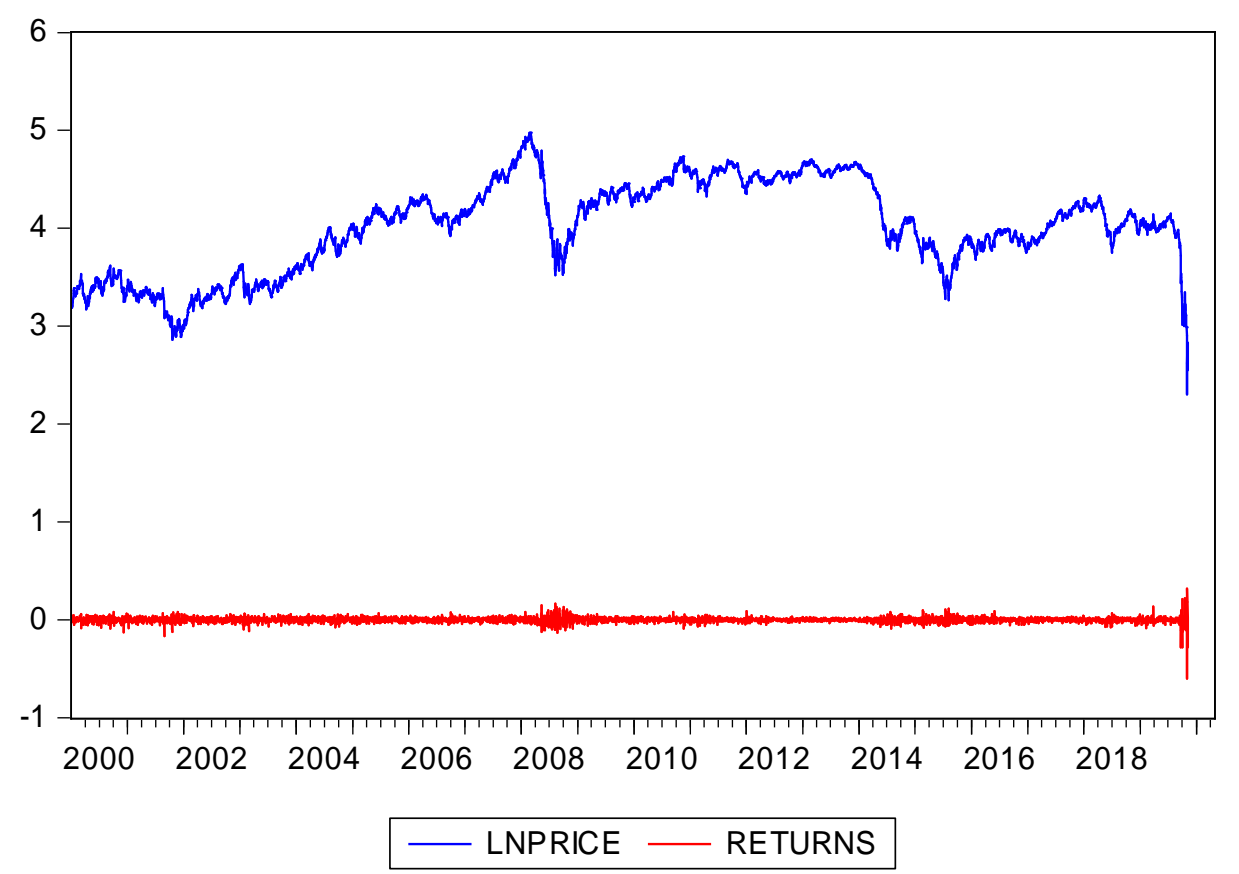

Fig. 2: Time plot of daily Crude Oil WTI Futures Historical log Stock Prices and returns from $4^{\text {th }}$ January 2000 to $27^{\text {th }}$ April 2020

Fig. 2 represents the time plot of the daily crude oil futures stock prices and returns. The highest stock price occurred during the global financial crisis of mid 2007 and early 2009 but the least stock price occurred during the COVID-19 crisis which indicated that crude oil futures is was hit by the COVID-19 pandemic as shown in figure 1 above. In addition, high volatility occurred during 2008 and 2020.

Table 2: Data Summary for Global Financial Crisis and COVID-19 periods for Daily Crude Oil WTI Futures Historical log Stock Prices and returns

\begin{tabular}{|l|l|r|r|r|r|r|r|}
\hline Variables & Mean & Max. & Min. & SD & Skewness & Kurtosis & JB \\
\hline \multicolumn{7}{|c|}{ Changes in log Prices and Returns (Sub Sample)( Global Financial Crisis)(07/02/2007- } \\
03/31/2009); T=441 \\
\hline Prices & 87.08717 & 145.2900 & 33.87000 & 29.19467 & -0.092384 & 2.108793 & $\mathbf{1 5 . 2 2 1 6 7}$ \\
\hline Log Prices & 4.401270 & 4.978730 & 3.522530 & 0.379896 & -0.666958 & 2.420314 & $\mathbf{3 8 . 8 6 9 9 1}$ \\
\hline Returns & -0.000815 & 0.164100 & -0.130650 & 0.037183 & 0.241625 & 5.766774 & $\mathbf{1 4 4 . 6 2 3 8}$ \\
\hline \multicolumn{7}{|c|}{ ARCH LM-test: Chi-squared = 77.812, df = 12, p-value = 1.077e-11 } \\
\hline \multicolumn{7}{|c|}{ 04/27/2020); T=84 } \\
\hline Changes in log Prices and Returns (Sub Sample)( COVID-19 Crisis)(01/01/2020- \\
\hline Prices & 41.24000 & 63.27000 & 10.01000 & 16.00244 & -0.354087 & 1.562482 & $\mathbf{8 . 9 8 7 8 9 5}$ \\
\hline Log Prices & 3.624131 & 4.147410 & 2.303580 & 0.468918 & -0.749329 & 2.349135 & $\mathbf{9 . 3 4 3 6 0 7}$ \\
\hline Returns & -0.018896 & 0.319640 & -0.601680 & 0.107638 & -1.754768 & 13.93005 & $\mathbf{4 5 5 . 7 4 8 9}$
\end{tabular}




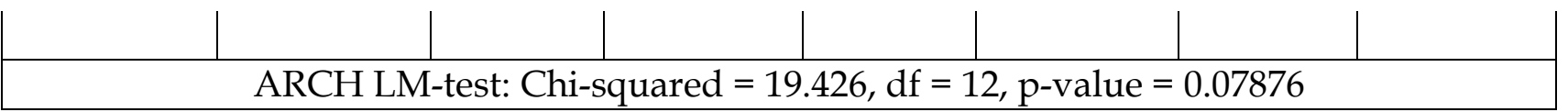

In bold significant Jarque-Bera (JB) test at $5 \%$ level of significance.

The table 2 above presents the descriptive statistics of the daily crude oil futures during the global financial crisis and COVID-19 crisis. During the global financial crisis price from $2^{\text {nd }}$ July 2007 to $31^{\text {st }}$ March 2009. During the global financial crisis, the mean price of crude oil futures was $\$ 87.08717$ with maximum stock price for Crude oil futures was $\$ 145.2900$ minimum stock price for the crude oil futures was $\$ 38.87$. The price had high standard deviation with negative skewness with a moderate kurtosis but the stock price was not normally distributed using JarqueBera (JB) statistic. The log stock price revealed an average of 4.401270, maximum value of 4.978730, minimum value of 3.522530 with standard deviation of 0.379896 , having a negative skewness but have a moderate value of kurtosis but log price of the crude oil futures was not normally distributed. The $\log$ returns of crude oil futures during the global financial crisis exhibited a negative mean (-0.000815) which signifies a loss in stock returns during the global financial crisis. In addition, 0.164100 was maximum returns, -0.130650 was minimum returns with standard deviation of 0.037183 , but the returns exhibited negative skewness and high kurtosis value of 5.766774 and finally, the returns series was not normally distributed and there is evidence of arch effects in the returns series.

The table 2 above further presents the descriptive statistics of the daily crude oil futures during the COVID-19 pandemic. During the COVID-19 crisis price from $1^{\text {st }}$ January 2020 to $27^{\text {th }}$ April 2020. During this present COVID-19 crisis, the mean price of crude oil futures was $\$ 41.24000$ with maximum stock price for Crude oil futures was $\$ 63.27000$, minimum stock price for the crude oil futures was $\$ 10.01000$. The price had high standard deviation with negative skewness with a low kurtosis but the stock price was not normally distributed using Jarque-Bera (JB) statistic. The log stock price revealed an average of 3.624131, maximum value of 4.147410, minimum value of 2.303580 with standard deviation of 0.468918 , having a negative skewness but have a moderate value of kurtosis but log price of the crude oil futures was not normally distributed. The log returns of crude oil futures during the global financial crisis exhibited a negative mean (-0.018896) which signifies a loss in stock returns during the present COVID-19 pandemic. In addition, 0.319640 was maximum returns, -0.601680 was minimum returns with 
standard deviation of 0.107638 , but the returns exhibited negative skewness and high kurtosis value of 13.93005 and finally, the returns series was not normally distributed and there was no evidence of arch effects in the returns series.

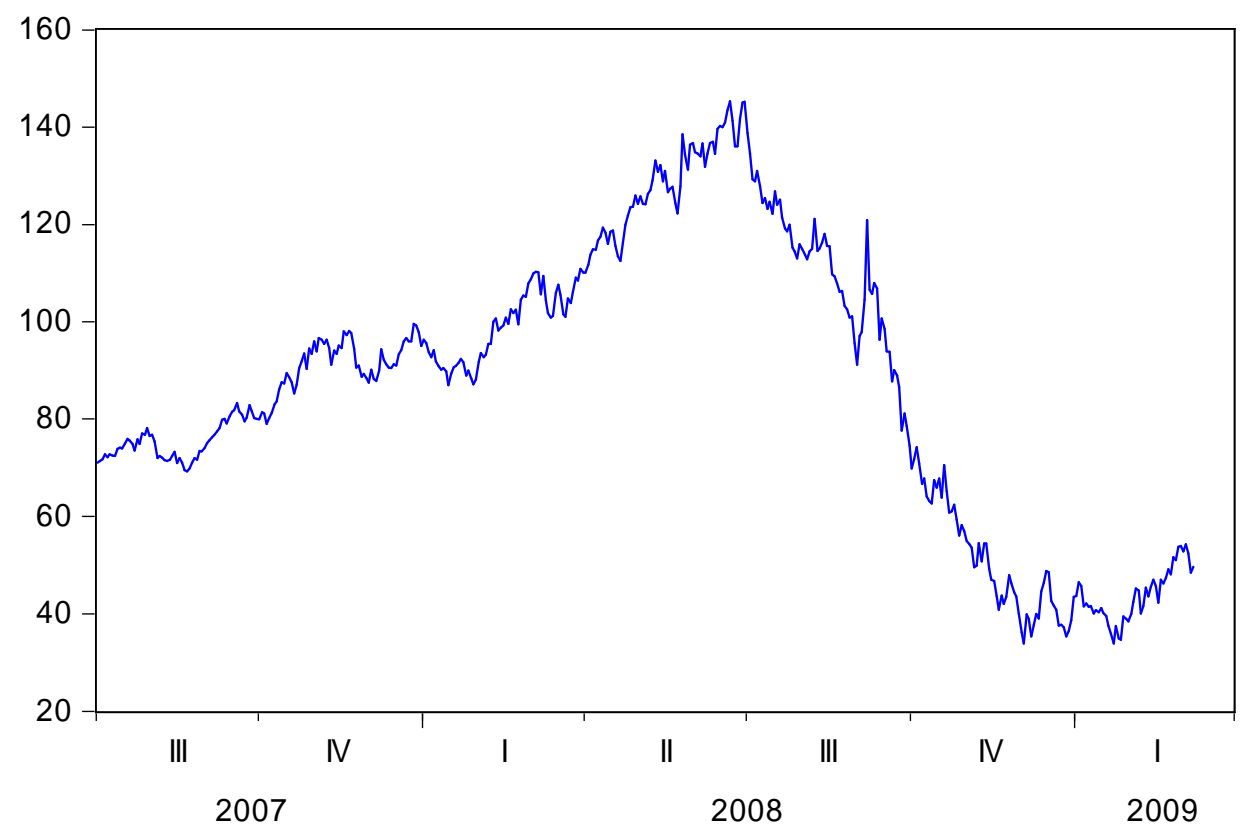

Fig. 3: Time plot of daily Crude Oil WTI Futures Historical Stock Prices from 2nd July 2007 to 31 ${ }^{\text {st } M a r c h ~} 2009$ during the Global Financial Crisis

Fig. 3 presents the time plot of the daily crude oil futures stock prices, the stock price got to its peak in 2008 and got to it least price in late 2008 during the global financial crisis. 


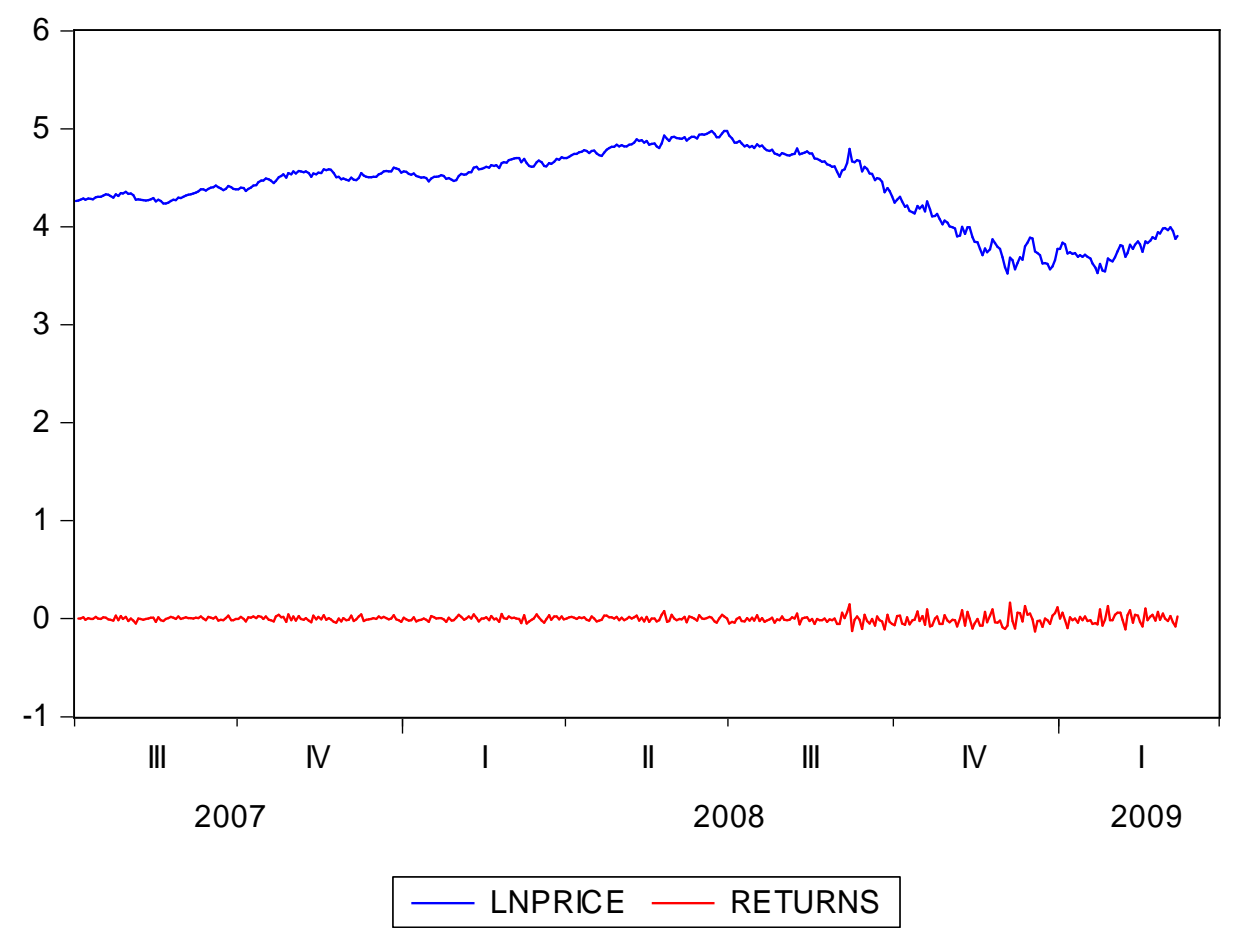

Fig. 4: Time plot of daily Crude Oil WTI Futures Historical log Stock Prices and returns from 2ndJuly 2007 to 31 ${ }^{\text {st }}$ March 2009 during the Global Financial Crisis

Fig. 4 presents the time plot of the daily crude oil futures stock prices and returns, the stock price got to its peak in 2008 and got to it least price in late 2008 during the global financial crisis. While the returns during the global financial crisis period exhibited high volatility during late 2008 to early 2009. 


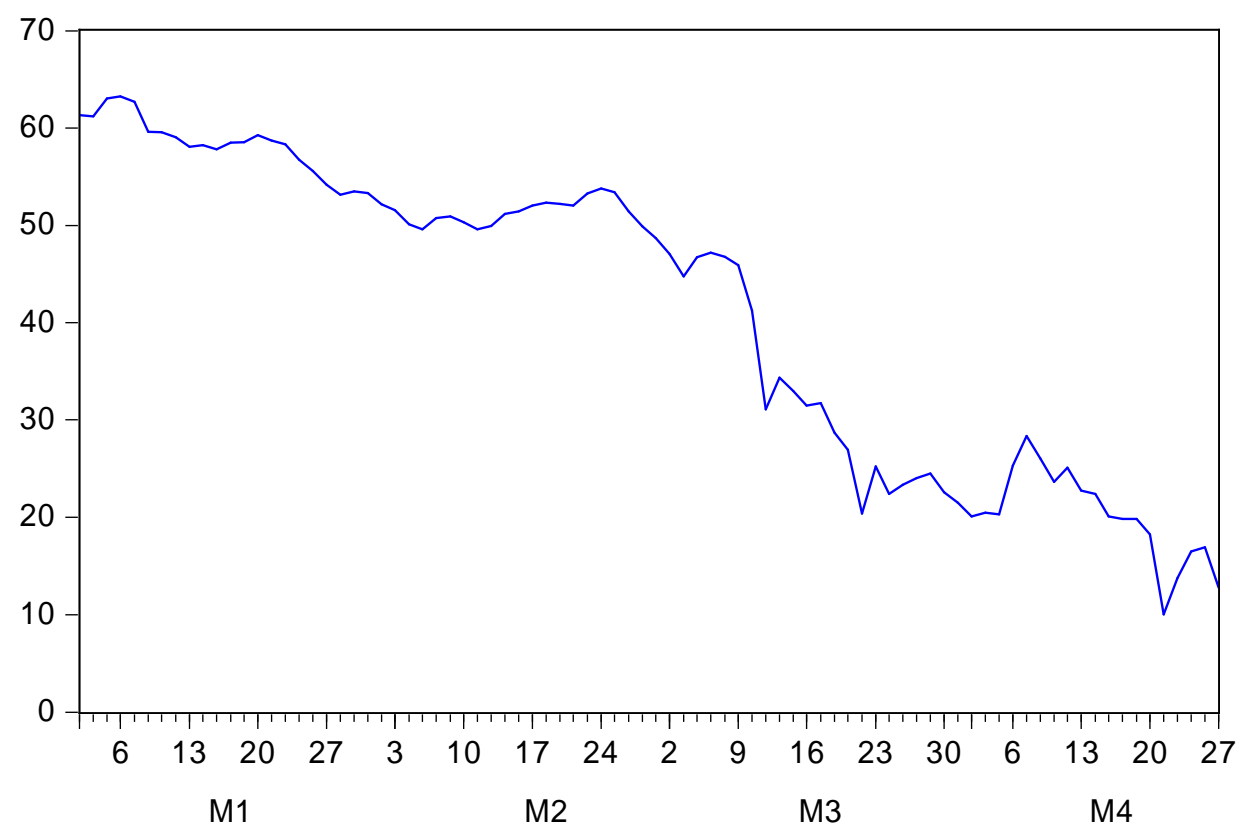

Fig. 5: Time plot of Daily Crude Oil WTI Futures Historical Stock Prices from $1^{\text {st }}$ January 2020 to 27th April 2020 during the COVID-19 Crisis

Fig. 5 presents the time plot of the daily crude oil futures stock prices, the stock price shows almost steady decline in the crude oil futures during this present COVID-19 crisis. 


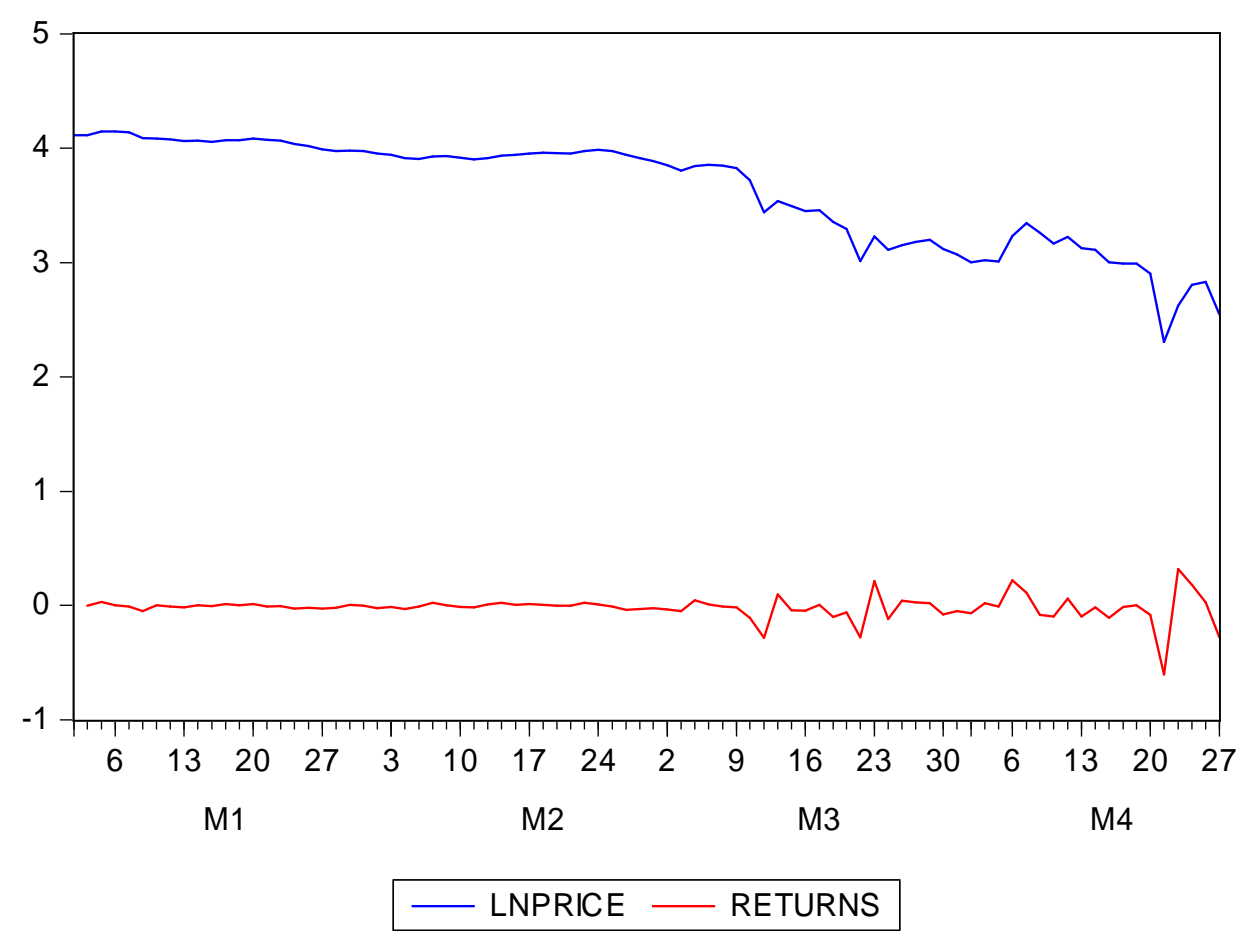

Fig. 6: Time plot of Daily Crude Oil WTI Futures Historical log Stock Prices and returns from 1stJanuary 2020 to $27^{\text {th }}$ April 2020 during the COVID-19 Crisis

Fig. 6 presents the time plot of the daily crude oil futures stock prices and returns, the stock price and returns shows almost steady decline in the crude oil futures during this present COVID-19 crisis.

Table 3: Results of classical Unit root tests for the full sample of daily Crude Oil WTI Futures Historical log Stock Prices and returns

\begin{tabular}{|l|r|r|r|}
\hline Variables & ADF & DF-GLS & PP \\
\hline \multicolumn{3}{|c|}{ Daily log Stock Prices (Full Sample) (01/04/2000-04/27/2020) } \\
\hline Price & -0.665333 & -0.848454 & -0.040579 \\
\hline \multicolumn{3}{|c|}{$\log$ Stock Returns (Full Sample) (01/04/2000-04/27/2020) } \\
\hline Returns & $-\mathbf{- 1 0 . 7 8 5 3 3}$ & -1.553130 & $\mathbf{- 7 6 . 1 0 6 6 6}$ \\
\hline
\end{tabular}

The bold denotes evidence of no unit root in the series.

The unit root testing was carried using ADF, DF-GLS and PP test on the daily crude oil stock prices and returns. In the table 3 above, the stock price of the crude oil for the full sample was not stationary but for the stock returns for the full sample was stationary. 
Table 4: Results of classical Unit root tests for of daily Crude Oil WTI Futures Historical log Stock returns during Global Financial Crisis and COVID-19 periods

\begin{tabular}{|c|c|c|c|}
\hline Variables & ADF & DF-GLS & $\mathbf{P P}$ \\
\hline \multicolumn{4}{|c|}{$\begin{array}{r}\text { Changes in log Returns (Sub Sample)( Global Financial Crisis) } \\
(07 / 02 / 2007-03 / 31 / 2009)\end{array}$} \\
\hline Returns & -10.33401 & -10.06433 & -22.82286 \\
\hline \multicolumn{4}{|c|}{$\begin{array}{l}\text { Changes in log Returns (Sub Sample)( COVID-19 Crisis) } \\
(01 / 01 / 2020-04 / 27 / 2020)\end{array}$} \\
\hline Returns & -7.865041 & -3.678082 & -19.84101 \\
\hline
\end{tabular}

The bold denotes evidence of no unit root in the series.

The unit root testing was carried using ADF, DF-GLS and PP test on the daily crude oil stock prices and returns during the global financial crisis and COVID-19 crisis. In the table 4 above, the stock returns of the crude oil for the Crisis periods (global financial crisis and COVID-19 crisis) was stationary.

Table 5: Data Summary for weekly Crude Oil WTI Futures Historical Stock Prices and Returns

\begin{tabular}{|l|l|c|c|c|c|c|c|}
\hline Variables & Mean & Max. & Min. & SD & Skewness & Kurtosis & JB \\
\hline \multicolumn{7}{|c|}{ Weekly Oil Futures Stock Price (Full Sample)(01/02/2000-04/26/2020); T=1061 } \\
\hline Price & 61.50608 & 145.2900 & 15.54000 & 26.25941 & 0.408256 & 2.359689 & 47.59864 \\
\hline Weekly Oil Futures log Stock Price (Full Sample) (01/02/2000-04/26/2020); T=1061 \\
\hline Log(Price) & 4.020047 & 4.978732 & 2.743417 & 0.459732 & -0.328132 & 2.209632 & 46.65590 \\
\hline \multicolumn{7}{|c|}{ Changes in Prices (Log-Returns) (01/02/2000-04/26/2020); T=1060 } \\
\hline Returns & -0.000419 & 0.275756 & -0.346863 & 0.053635 & -0.941030 & 8.829281 & 1657.251 \\
\hline
\end{tabular}

In bold significant Jarque-Bera (JB) test at $5 \%$ level of significance.

The table 1 presents the descriptive statistics of the weekly crude oil futures price from the $2^{\text {nd }}$ January 2000 to $26^{\text {th }}$ April 2020. the maximum stock price for Crude oil futures was $\$ 145.2900$ that occurred during the global financial crisis and the minimum stock price for the crude oil futures was $\$ 15.54000$ which occurred during the COVID-19 crisis. The price had high standard deviation with positive skewness with a moderate kurtosis but the stock price was 
not normally distributed using Jarque-Bera (JB) statistic. The log stock price revealed an average of 4.020047 , maximum value of 4.978732 , minimum value of 2.743417 with standard deviation of 0.459732 , having a negative skewness but have a similar value of kurtosis as the stock price of the crude oil futures and the log price series was not normally distributed. The log returns of crude oil futures exhibited a negative mean (-0.000419) which signifies a loss in stock returns over the period under consideration. In addition, 0.275756 was maximum returns, 0.346863 was minimum returns with standard deviation of 0.053635 , but the returns exhibited negative skewness and high kurtosis value of 8.829281 and finally, the returns series was not normally distributed and there is evidence of arch effects in the returns series.

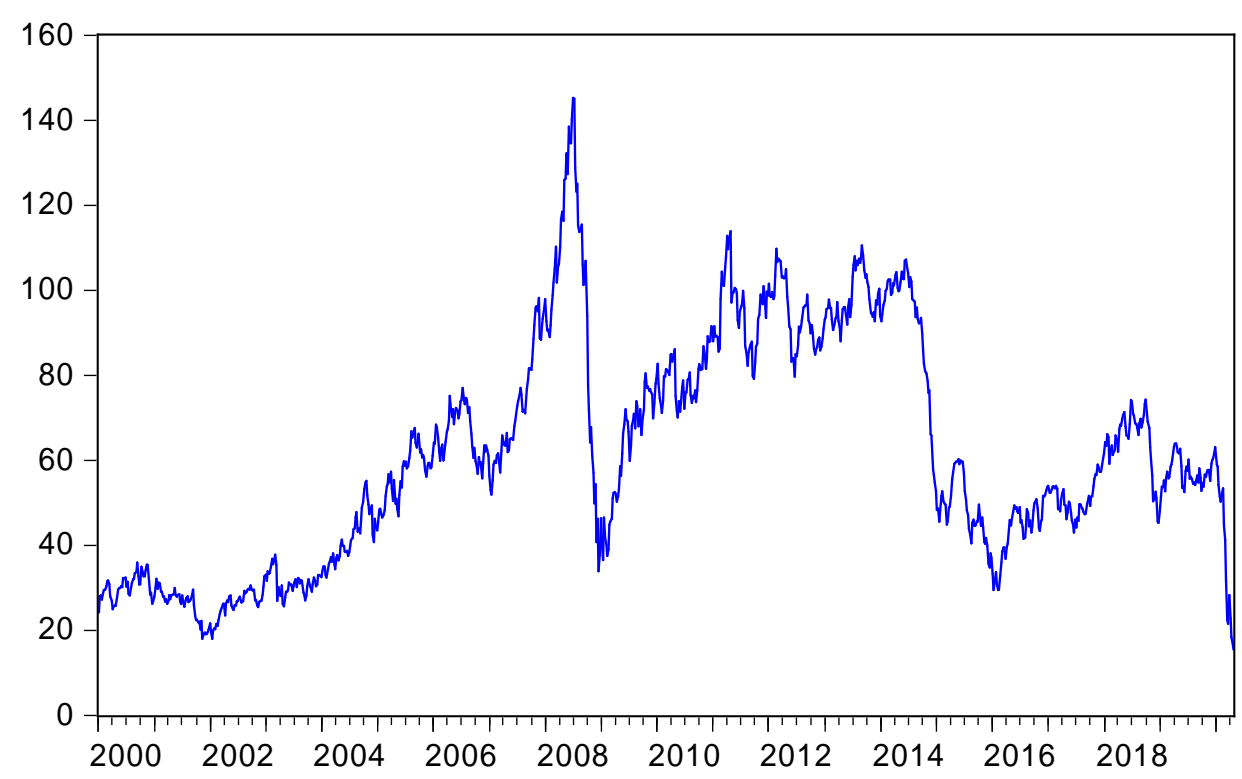

Fig. 7: Time plot of weekly Crude Oil WTI Futures Historical Stock Prices from 2nd January 2000 to $26^{\text {th }}$ April 2020

Fig. 7 represents the time plot of the weekly crude oil futures stock prices. The highest stock price occurred during the global financial crisis of mid 2007 and early 2009 but the least stock price occurred during the COVID-19 crisis which indicated that crude oil futures was worse hit by the COVID-19 pandemic. 


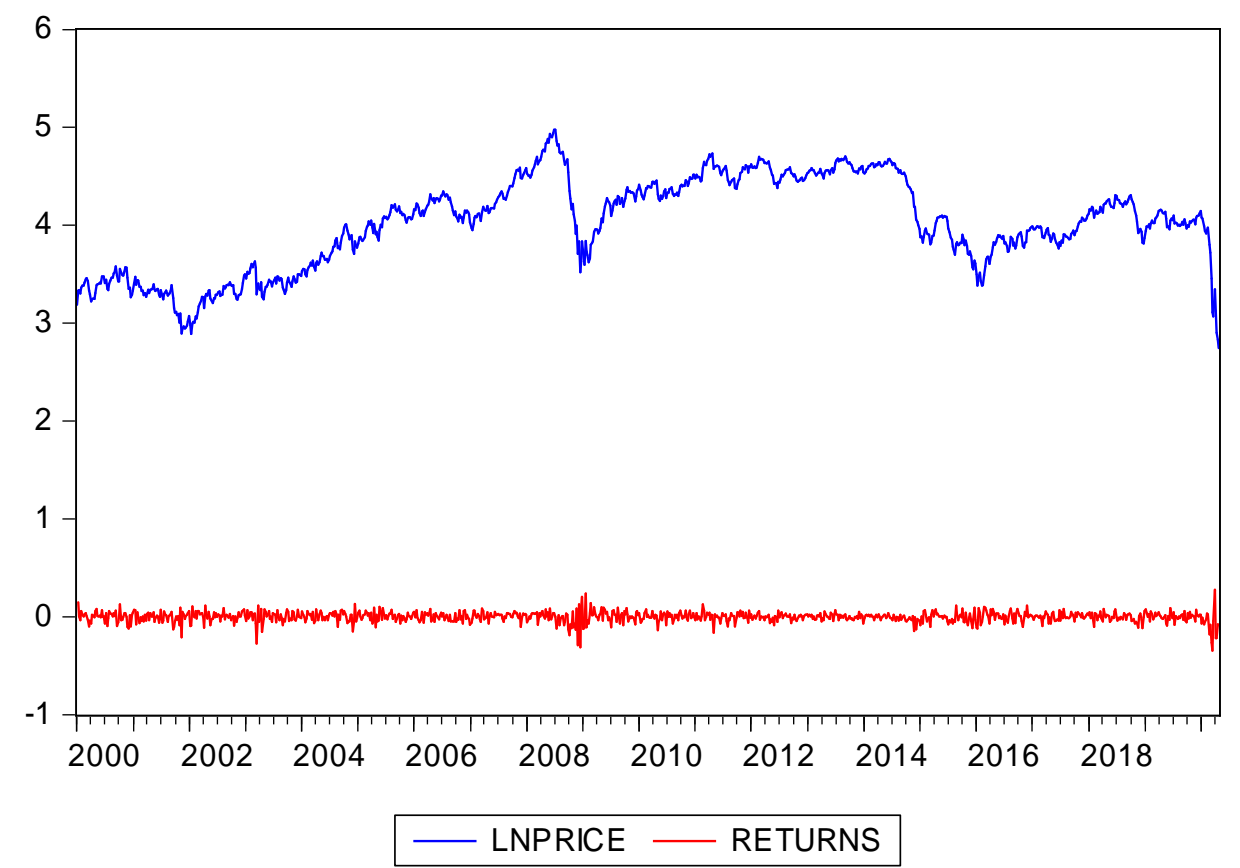

Fig. 8: Time plot of weekly Crude Oil WTI Futures Historical log Stock Prices and returns from $2^{\text {nd }}$ January 2000 to $26^{\text {th }}$ April 2020

Fig. 8 represents the time plot of the daily crude oil futures stock prices and returns. The highest stock price occurred during the global financial crisis of mid 2007 and early 2009 but the least stock price occurred during the COVID-19 crisis which indicated that crude oil futures was worse hit by the COVID-19 pandemic as shown in figure 7 above. In addition, high volatility occurred during 2008 and 2020. 
Table 6: Data Summary for Global Financial Crisis and COVID-19 periods for weekly Crude Oil WTI Futures Historical log Stock Prices and returns

\begin{tabular}{|l|l|r|r|r|r|r|r|}
\hline Variables & Mean & Max. & Min. & SD & Skewness & Kurtosis & JB \\
\hline \multicolumn{7}{|c|}{ Changes in log Prices and Returns (Sub Sample)( Global Financial Crisis)(07/01/2007- } \\
03/29/2009); T=92 \\
\hline Prices & 86.88424 & 145.2900 & 33.87000 & 29.77744 & -0.047261 & 2.115187 & 3.035339 \\
\hline Log Prices & 4.397053 & 4.978732 & 3.522530 & 0.386306 & -0.626704 & 2.360243 & 7.591231 \\
\hline Returns & -0.003230 & 0.241221 & -0.312180 & 0.082045 & -0.799504 & 6.217034 & 49.47352 \\
\hline \multicolumn{7}{|c|}{ ARCH LM-test: Chi-squared = 38.617, df = 12, p-value = 0.0001217 } \\
\hline Changes in log Prices and Returns (Sub Sample)( COVID-19 Crisis)(01/05/2020- \\
\hline Prices & 37.80235 & 59.04000 & 15.54000 & 16.14110 & -0.083993 & 1.360779 & 1.923312 \\
\hline Log Prices & 3.531572 & 4.078215 & 2.743417 & 0.481373 & -0.343834 & 1.527560 & 1.870684 \\
\hline Returns & -0.082383 & 0.275756 & -0.346863 & 0.140145 & 0.446374 & 4.055285 & 1.353361 \\
\hline & ARCH LM-test: Chi-squared = 5, df = 12, p-value = 0.958 \\
\hline
\end{tabular}

In bold significant Jarque-Bera (JB) test at $5 \%$ level of significance.

The table 6 above presents the descriptive statistics of the weekly crude oil futures during the global financial crisis and COVID-19 crisis. During the global financial crisis price from $1^{\text {st }}$ July 2007 to $29^{\text {th }}$ March 2009. During the global financial crisis, the mean price of crude oil futures was $\$ 86.88424$ with maximum stock price for Crude oil futures was $\$ 145.2900$ minimum stock price for the crude oil futures was $\$ 33.87000$. The price had high standard deviation with negative skewness with a moderate kurtosis but the stock price was normally distributed using Jarque-Bera (JB) statistic. The log stock price revealed an average of 4.397053, maximum value of 4.978732 , minimum value of 3.522530 with standard deviation of 0.386306 , having a negative skewness but have a moderate value of kurtosis but log price of the crude oil futures was not normally distributed. The log returns of crude oil futures during the global financial crisis exhibited a negative mean (-0.003230) which signifies a loss in stock returns during the global financial crisis. In addition, 0.241221 was maximum returns, -0.312180 was minimum returns with standard deviation of 0.082045 , but the returns exhibited negative skewness and high kurtosis value of 6.217034 and finally, the returns series was not normally distributed and there is evidence of arch effects in the returns series. 
The table 6 above further presents the descriptive statistics of the weekly crude oil futures during the COVID-19 pandemic. During the COVID-19 crisis price from $5^{\text {th }}$ January 2020 to $26^{\text {th }}$ April 2020. During this present COVID-19 crisis, the mean price of crude oil futures was $\$ 37.80235$ with maximum stock price for Crude oil futures was $\$ 59.04000$, minimum stock price for the crude oil futures was $\$ 15.54000$. The price had high standard deviation with negative skewnesswith a low kurtosis but the stock price was normally distributed using Jarque-Bera (JB) statistic. The log stock price revealed an average of 3.531572, maximum value of 4.078215, minimum value of 2.743417 with standard deviation of 0.481373 , having a negative skewness but have a low value of kurtosis but log price of the crude oil futures was normally distributed. The log returns of crude oil futures during the present COVID-19 crisis exhibited a negative mean (-0.082383) which signifies a loss in stock returns during the present COVID-19 pandemic. In addition, 0.275756 was maximum returns, -0.346863 was minimum returns with standard deviation of 0.140145 , but the returns exhibited positive skewness and high kurtosis value of 4.055285 and finally, the returns series was normally distributed and there was no evidence of arch effects in the returns series.

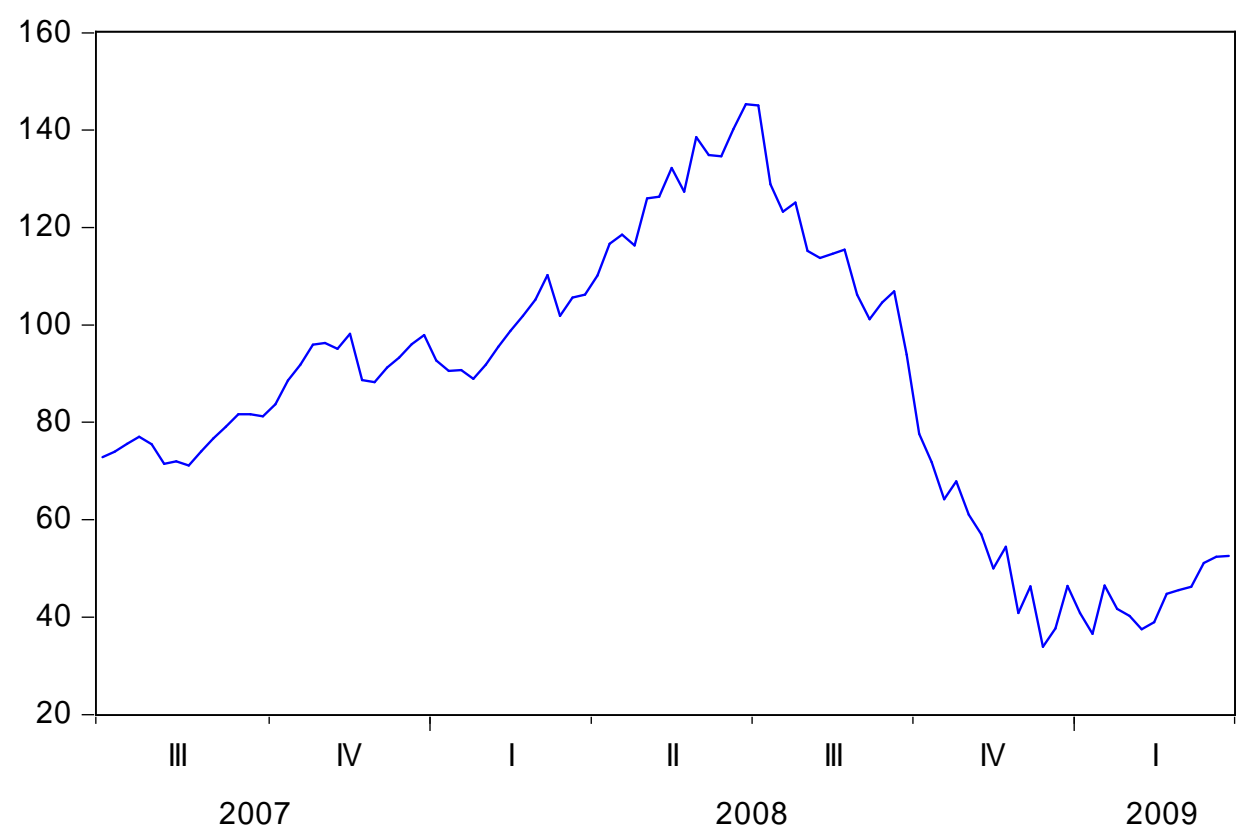

Fig. 9: Time plot of weekly Crude Oil WTI Futures Historical Stock Prices from $1^{\text {st }}$ July 2007 to $29^{\text {th }}$ March 2009 during the Global Financial Crisis 
Fig 9 above presents the time plot of weekly crude oil futures during the global financial crisis from $1^{\text {st }}$ July 2007 to $29^{\text {th }}$ March 2009. The crude reached its peak around 2008 but fell towards the end of 2008 and began to rise around early 2009.

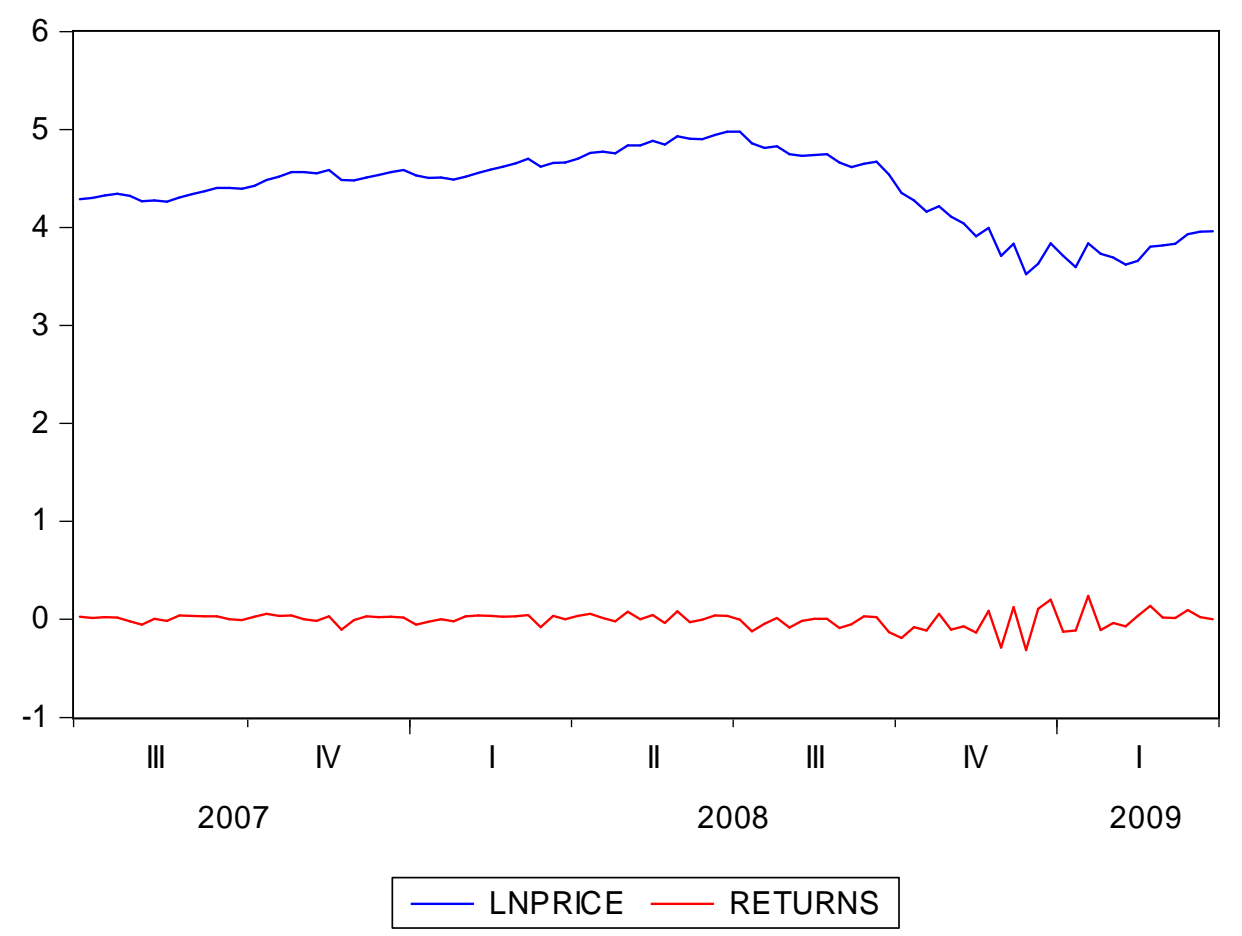

Fig. 10: Time plot of weekly Crude Oil WTI Futures Historical log Stock Prices and returns from $1^{\text {st }}$ July 2007 to $29^{\text {th }}$ March 2009 during the Global Financial Crisis

Fig 10 presents the time plot of weekly crude oil futures log stock prices and returns.

The log stock prices and returns almost exhibited similar pattern during the global financial crisis as shown in fig. 9 above. 


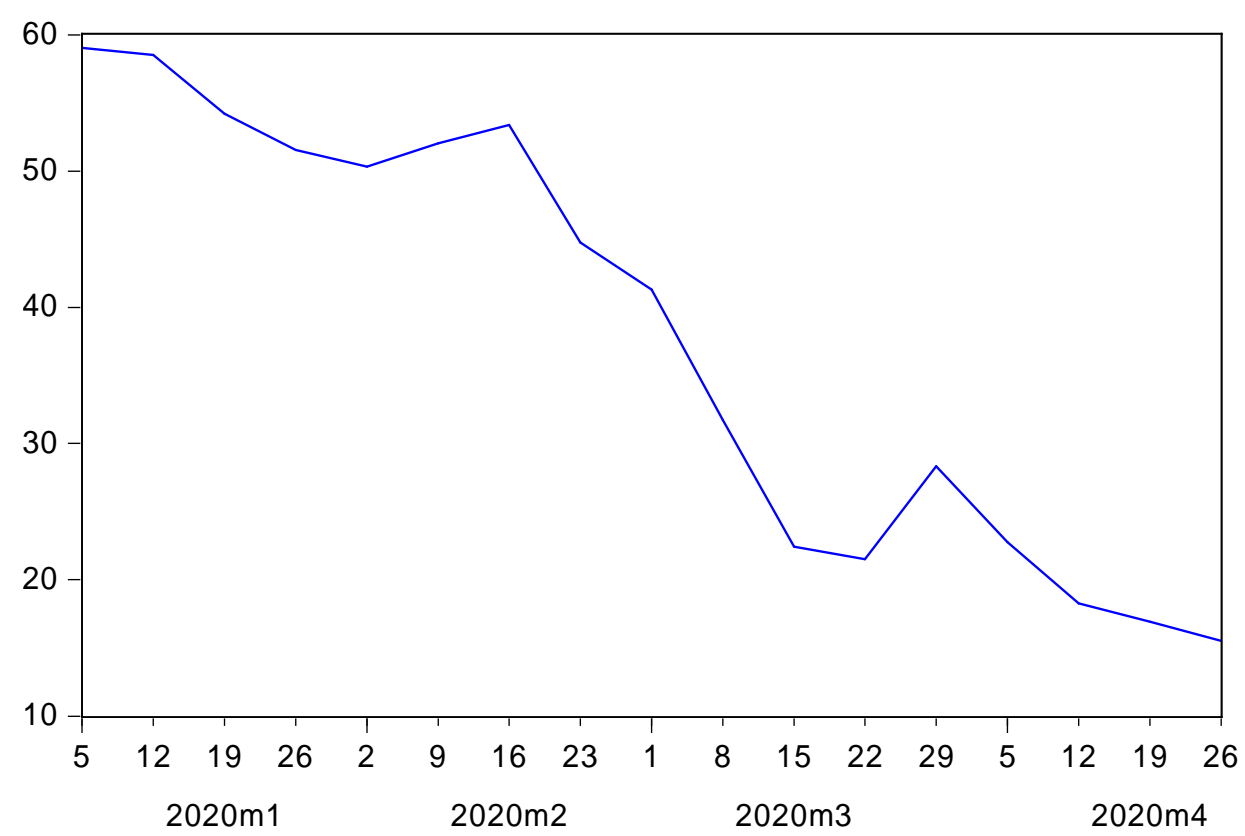

Fig. 11: Time plot of weekly Crude Oil WTI Futures Historical Stock Prices from $5^{\text {th }}$ January 2020 to $26^{\text {th }}$ April 2020 during the COVID-19 Crisis

Fig. 11 presents the time plot of the weekly crude oil futures stock prices from $5^{\text {th }}$ January 2020 to $26^{\text {th }}$ April 2020 during the COVID-19 Crisis, the stock price shows almost steady decline in the crude oil futures during this present COVID-19 crisis. 


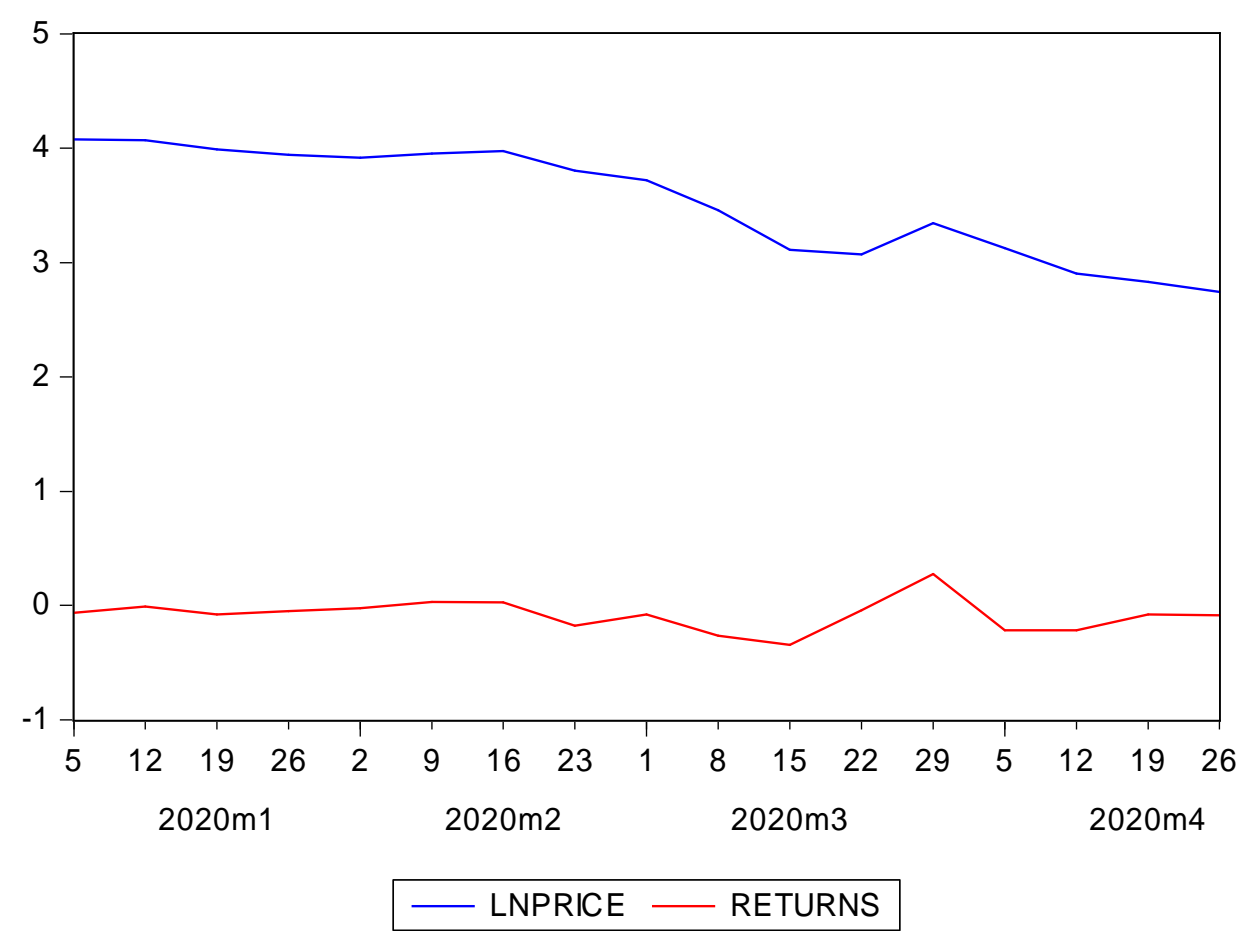

Fig. 12: Time plot of weekly Crude Oil WTI Futures Historical log Stock Prices and returns from $5^{\text {th }}$ January 2020 to $26^{\text {th }}$ April 2020 during the COVID-19 Crisis

Fig. 12 presents the time plot of the weekly crude oil futures stock prices and returns from $5^{\text {th }}$ January 2020 to $26^{\text {th }}$ April 2020 during the COVID-19 Crisis, the stock price shows almost steady decline in the crude oil futures during this present COVID-19 crisis. This is similar to the pattern in fig. 11 above. 
Table 7: Results of classical Unit root tests for the full sample of weekly Crude Oil WTI Futures Historical log Stock Prices and returns

\begin{tabular}{|l|r|r|r|}
\hline Variables & ADF & DF-GLS & PP \\
\hline \multicolumn{2}{|c|}{ Weekly log Stock Prices (Full Sample) (01/02/2000-04/26/2020) } \\
\hline Price & -1.078611 & -1.133820 & -0.955158 \\
\hline \multicolumn{3}{|c|}{ Weekly log Stock Returns (Full Sample) (01/02/2000-04/26/2020) } \\
\hline Returns & -8.639748 & -1.935963 & $-\mathbf{- 3 2 . 4 5 5 4 8}$ \\
\hline
\end{tabular}

The bold denotes evidence of no unit root in the series.

The unit root testing was carried using ADF, DF-GLS and PP test on the weekly crude oil stock prices and returns. In the table 7 above, the stock price of the crude oil for the full sample was not stationary but for the stock returns for the full sample was stationary.

Table 8: Results of classical Unit root tests for of weekly Crude Oil WTI Futures Historical log Stock returns during Global Financial Crisis and COVID-19 periods

\begin{tabular}{|c|c|c|c|}
\hline Variables & ADF & DF-GLS & PP \\
\hline \multicolumn{4}{|c|}{$\begin{array}{r}\text { Changes in log Returns (Sub Sample)( Global Financial } \\
\text { Crisis)(07/01/2007-03/29/2009) }\end{array}$} \\
\hline Returns & -11.56338 & -11.64046 & -11.37650 \\
\hline \multicolumn{4}{|c|}{$\begin{array}{l}\text { Changes in log Returns (Sub Sample)( COVID-19 Crisis) } \\
(01 / 05 / 2020-04 / 26 / 2020)\end{array}$} \\
\hline Returns & -3.947376 & -4.287342 & -4.745650 \\
\hline
\end{tabular}

The bold denotes evidence of no unit root in the series.

The unit root testing was carried using ADF, DF-GLS and PP test on the weekly crude oil stock prices and returns during the global financial crisis and COVID-19 crisis. In the table 8 above, the stock returns of the crude oil for the Crisis periods (global financial crisis and COVID-19 crisis) were stationary.

\section{Results and Analysis}

This section focused on univariate time series analysis and the univariate GARCH analysis of the daily and weekly stock prices and returns by including global financial crisis and COVID-19 crisis as dummy variables. 
Table 9: ARIMAX models for daily log stock prices and Returns

\begin{tabular}{|c|c|c|c|}
\hline $\begin{array}{l}\text { Variable/ } \\
\text { Model }\end{array}$ & Parameters & Estimates & Diagnostics (Residual) \\
\hline $\begin{array}{l}\text { Lnprice } \\
\text { ARIMAX } \\
(1,1,0)\end{array}$ & $\begin{array}{l}\operatorname{arl} \\
\text { drift } \\
\text { gfc } \\
\text { covid-19 }\end{array}$ & $\begin{array}{lrrrr}\text { Estimate } & \text { Std. Error } z \text { value } & \text { Pr }(>|z|) & \\
-0.06358227 & 0.01402761 & -4.5327 & 5.825 e-06 \\
-0.00012606 & 0.00035371 & -0.3564 & 0.7215 \\
0.01301898 & 0.01909251 & 0.6819 & 0.4953 \\
0.00370576 & 0.02699016 & 0.1373 & 0.8908\end{array}$ & $\begin{array}{l}\text { JB test: } \mathrm{p}:<2.2 \mathrm{e}-16 \\
\text { Box-Ljung test: } \mathrm{p}=2.442 \mathrm{e}-15 \\
\text { ARCH LM-test, } \mathrm{p}<2.2 \mathrm{e}-16\end{array}$ \\
\hline $\begin{array}{l}\text { Returns } \\
\text { ARIMAX } \\
(1,0,0)\end{array}$ & $\begin{array}{l}\operatorname{ar} 1 \\
\text { constant } \\
\text { gfc } \\
\text { covid-19 }\end{array}$ & \begin{tabular}{lcll|l} 
Estimate & Std. Error $z$ & value $\operatorname{Pr}(>|z|)$ & \\
$-5.0468 e-01$ & $1.2106 e-02$ & -41.6897 & $<2 e-16$ \\
$-2.4294 e-05$ & $3.1456 e-04$ & -0.0772 & 0.9384 \\
$-2.1158 e-02$ & $2.1476 e-02$ & -0.9852 & 0.3245 \\
$7.2135 e-03$ & $3.0366 e-02$ & 0.2376 & 0.8122
\end{tabular} & $\begin{array}{l}\text { JB test: } p:<2.2 e-16 \\
\text { Box-Ljung test: } p<2.2 e-16 \\
\text { ARCH LM-test, } p<2.2 e-16\end{array}$ \\
\hline
\end{tabular}

The Auto.arima function in $\mathrm{R}$ software was used to implement the best ARIMA model for the $\log$ stock price and returns as presented in table 9 above. For the log stock prices ARIMAX $(1,1,0)$ was optimal for the daily crude oil futures and the autoregressive coefficient was significant while the global financial crisis (gfc)and the impact of COVID-19 were positive but not significant. The model was not adequate while the residual is not normally distributed and exhibited Arch effects.

For the log returns $\operatorname{ARIMAX}(1,0)$ was optimal for the daily crude oil futures returns and the autoregressive coefficient was significant while the impact of global financial crisis (gfc) was negative and the impact of COVID-19 was positive but not significant. The model was not adequate while the residual is not normally distributed and exhibited Arch effects.

Table 10: GARCH models and their performance on the log returns of daily Crude Oil WTI Futures Historical log Stock returns

\begin{tabular}{|l|l|l|l|}
\hline Model & $\begin{array}{l}\text { Information } \\
\text { criteria }\end{array}$ & $\begin{array}{l}\text { Std } \\
\text { innovation }\end{array}$ & $\begin{array}{l}\text { Skewed stdt } \\
\text { innovation }\end{array}$ \\
\hline ARMA $(1,0)-$ SGARCH & Akaike & -4.8878 & -4.8919 \\
$(1,1)$ & Bayes & -4.8777 & -4.8805 \\
& Shibata & -4.8878 & -4.8919 \\
& Hannan-Quinn & -4.8843 & -4.8879 \\
\hline ARMA $(1,0)-$ SGARCH & Akaike & -4.8874 & -4.8915 \\
$(2,1)$ & Bayes & -4.8761 & -4.8789 \\
& Shibata & -4.8875 & -4.8915 \\
& Hannan-Quinn & -4.8835 & -4.8871 \\
\hline
\end{tabular}




\begin{tabular}{|c|c|c|c|}
\hline $\begin{array}{l}\operatorname{ARMA}(1,0)- \\
\operatorname{sGARCH}(2,2)\end{array}$ & $\begin{array}{l}\text { Akaike } \\
\text { Bayes } \\
\text { Shibata } \\
\text { Hannan-Quinn }\end{array}$ & $\begin{array}{l}-4.8876 \\
-4.8750 \\
-4.8876 \\
-4.8832\end{array}$ & $\begin{array}{l}-4.8917 \\
-4.8777 \\
-4.8917 \\
-4.8868\end{array}$ \\
\hline $\begin{array}{l}\operatorname{ARMA}(1,0)- \\
\operatorname{eGARCH}(1,1)\end{array}$ & $\begin{array}{l}\text { Akaike } \\
\text { Bayes } \\
\text { Shibata } \\
\text { Hannan-Quinn }\end{array}$ & $\begin{array}{l}-4.9008 \\
-4.8894 \\
-4.9008 \\
-4.8968\end{array}$ & $\begin{array}{l}-3.6977 \\
-3.6850 \\
-3.6977 \\
-3.6933\end{array}$ \\
\hline $\begin{array}{l}\operatorname{ARMA}(1,0)- \\
\operatorname{eGARCH}(2,1)\end{array}$ & $\begin{array}{l}\text { Akaike } \\
\text { Bayes } \\
\text { Shibata } \\
\text { Hannan-Quinn }\end{array}$ & $\begin{array}{l}-4.0190 \\
-4.0051 \\
-4.0190 \\
-4.0142\end{array}$ & $\begin{array}{l}-4.9060 \\
-4.8908 \\
-4.9060 \\
-4.9007\end{array}$ \\
\hline $\begin{array}{l}\operatorname{ARMA}(1,0)- \\
\operatorname{eGARCH}(2,2)\end{array}$ & $\begin{array}{l}\text { Akaike } \\
\text { Bayes } \\
\text { Shibata } \\
\text { Hannan-Quinn }\end{array}$ & $\begin{array}{l}-3.2922 \\
-3.2770 \\
-3.2922 \\
-3.2869\end{array}$ & $\begin{array}{l}-3.4658 \\
-3.4494 \\
-3.4658 \\
-3.4601\end{array}$ \\
\hline $\begin{array}{l}\text { ARMA }(1,0)-\text { TGARCH } \\
(1,1)\end{array}$ & $\begin{array}{l}\text { Akaike } \\
\text { Bayes } \\
\text { Shibata } \\
\text { Hannan-Quinn }\end{array}$ & $\begin{array}{l}-4.8978 \\
-4.8864 \\
-4.8978 \\
-4.8938\end{array}$ & $\begin{array}{l}-4.9031 \\
-4.8904 \\
-4.9031 \\
-4.8986\end{array}$ \\
\hline $\begin{array}{l}\text { ARMA }(1,0)-\text { TGARCH } \\
(2,1)\end{array}$ & $\begin{array}{l}\text { Akaike } \\
\text { Bayes } \\
\text { Shibata } \\
\text { Hannan-Quinn }\end{array}$ & $\begin{array}{l}-4.8967 \\
-4.8828 \\
-4.8967 \\
-4.8919\end{array}$ & $\begin{array}{l}-4.9019 \\
-4.8867 \\
-4.9019 \\
-4.8966\end{array}$ \\
\hline $\begin{array}{l}\text { ARMA }(1,0)-\text { TGARCH } \\
(2,2)\end{array}$ & $\begin{array}{l}\text { Akaike } \\
\text { Bayes } \\
\text { Shibata } \\
\text { Hannan-Quinn }\end{array}$ & $\begin{array}{l}-4.8971 \\
-4.8819 \\
-4.8971 \\
-4.8918\end{array}$ & $\begin{array}{l}-4.9022 \\
-4.8857 \\
-4.9022 \\
-4.8964\end{array}$ \\
\hline $\begin{array}{l}\operatorname{ARMA}(1,0)-\operatorname{apARCH} \\
(1,1)\end{array}$ & $\begin{array}{l}\text { Akaike } \\
\text { Bayes } \\
\text { Shibata } \\
\text { Hannan-Quinn }\end{array}$ & $\begin{array}{l}-4.8975 \\
-4.8848 \\
-4.8975 \\
-4.8931\end{array}$ & $\begin{array}{l}-4.9027 \\
-4.8888 \\
-4.9027 \\
-4.8978\end{array}$ \\
\hline $\begin{array}{l}\text { ARMA }(1,0)-\operatorname{apARCH} \\
(2,1)\end{array}$ & $\begin{array}{l}\text { Akaike } \\
\text { Bayes } \\
\text { Shibata } \\
\text { Hannan-Quinn }\end{array}$ & $\begin{array}{l}-4.8966 \\
-4.8814 \\
-4.8966 \\
-4.8913\end{array}$ & $\begin{array}{l}-4.9016 \\
-4.8851 \\
-4.9016 \\
-4.8958\end{array}$ \\
\hline $\begin{array}{l}\text { ARMA }(1,0)-\text { apARCH } \\
(2,2)\end{array}$ & $\begin{array}{l}\text { Akaike } \\
\text { Bayes } \\
\text { Shibata } \\
\text { Hannan-Quinn }\end{array}$ & $\begin{array}{l}-4.8969 \\
-4.8804 \\
-4.8969 \\
-4.8911\end{array}$ & $\begin{array}{l}-4.9019 \\
-4.8842 \\
-4.9019 \\
-4.8957\end{array}$ \\
\hline
\end{tabular}

The table 10 above presents the selection criteria values for daily crude oil futures based on the student $t$ and skewed student $t$ distributions. The ARMA model favoured the ARMA $(1,0)$ model 
while the competing GARCH models (that is sGARCH, eGARCH, TGARCH and apARCH) used a maximum lag of 2 . The selection criteria seems to be lowest for skewed student $t$ distribution compared to student $t$ distribution except in few cases. This is so because the return series was negatively skewed. Among the competing ARMA-GARCH models, ARMA(1,0)eGARCH $(2,1)$ with skewed student $t$ distribution had the least selection criteria values while $\operatorname{ARMA}(1,0)-\mathrm{eGARCH}(2,2)$ with student $t$ distribution. Hence $\operatorname{ARMA}(1,0)-\operatorname{eGARCH}(2,1)$ with skewed student $t$ distribution emerged as the superior model for daily crude oil futures with the effects of global financial crisis and the present COVID-19 crisis.

\section{Table 11: Persistence and Half-life Volatility of the GARCH models of daily Crude Oil WTI Futures Historical log Stock returns}

\begin{tabular}{|c|c|c|c|c|}
\hline Models & \multicolumn{2}{|c|}{ Std } & \multicolumn{2}{|c|}{ Skewed std } \\
\hline & Persistence & $\begin{array}{l}\text { Half-life } \\
\text { volatility }\end{array}$ & Persistence & $\begin{array}{l}\text { Half-life } \\
\text { volatility }\end{array}$ \\
\hline $\operatorname{ARMA}(1,0)-\mathrm{sGARCH} \quad(1,1)$ & 0.9960108 & 173.4107 & 0.9964886 & 197.053 \\
\hline $\operatorname{ARMA}(1,0)-\mathrm{sGARCH} \quad(2,1)$ & 0.996009 & 173.332 & 0.9964841 & 196.7971 \\
\hline $\operatorname{ARMA}(1,0)-\operatorname{sGARCH}(2,2)$ & 0.9945199 & 126.1372 & 0.9952017 & 144.1091 \\
\hline $\operatorname{ARMA}(1,0)-\operatorname{eGARCH}(1,1)$ & 0.9929212 & 97.57215 & 0.9000411 & 6.581664 \\
\hline $\operatorname{ARMA}(1,0)-\operatorname{eGARCH}(2,1)$ & 0.9000373 & 6.581402 & 0.9933146 & 103.3336 \\
\hline $\operatorname{ARMA}(1,0)-\operatorname{eGARCH}(2,2)$ & 0.9045431 & 6.908999 & 0.9038479 & 6.856448 \\
\hline $\operatorname{ARMA}(1,0)-\mathrm{TGARCH} \quad(1,1)$ & 0.9929981 & 98.64771 & 0.9936854 & 109.4224 \\
\hline $\operatorname{ARMA}(1,0)-\mathrm{TGARCH} \quad(2,1)$ & 0.9929672 & 98.21195 & 0.9936566 & 108.9235 \\
\hline $\operatorname{ARMA}(1,0)-\mathrm{TGARCH} \quad(2,2)$ & 0.9903821 & 71.72134 & 0.9914367 & 80.59655 \\
\hline $\operatorname{ARMA}(1,0)-\operatorname{apARCH}(1,1)$ & 0.993231 & 102.0528 & 0.9939653 & 114.5141 \\
\hline $\operatorname{ARMA}(1,0)-\operatorname{apARCH}(2,1)$ & 0.9929729 & 98.29285 & 0.9941062 & 117.2583 \\
\hline $\operatorname{ARMA}(1,0)-\operatorname{apARCH}(2,2)$ & 0.9908128 & 75.09959 & 0.9920549 & 86.8952 \\
\hline
\end{tabular}

Table 11 presented the persistence and half-life values for the competing models with the student $t$ and skewed student $t$ distributions. The entire ARMA-GARCH model exhibited very high persistence value though less than 1 (one), this could be due to the impact of global financial crisis and the present COVID-19 pandemic, but the entire model exhibited stability. For the $\operatorname{ARMA}(1,0)$-eGARCH$(2,1)$, the persistence value is 0.9933146 while it take about 104 days for mean-reverting to take place. 
Table 12: Backtesting of the ARMA(1,0)-eGARCH(2,1): GARCH Roll Forecast (Backtest Length: 1176) for Daily Crude Oil Futures

\begin{tabular}{|c|c|c|c|c|c|c|c|c|}
\hline Model & Distributions & Alpha & $\begin{array}{l}\text { Expected } \\
\text { Exceed }\end{array}$ & $\begin{array}{l}\text { Actual } \\
\text { VaR } \\
\text { Exceed }\end{array}$ & $\begin{array}{l}\text { Unconditiona } \\
\text { Coverage } \\
\mathrm{H}_{0} \text { : Correct } \\
\text { Exceedances }\end{array}$ & piec) & $\begin{array}{l}\text { Conditional } \\
\text { Coverage } \\
\text { (Christoffe } \\
\mathrm{H}_{0} \text { : Correct } \\
\text { Exceedances } \\
\text { independenc } \\
\text { Failure }\end{array}$ & $\begin{array}{l}\text { rsen) } \\
\text { and } \\
\text { of }\end{array}$ \\
\hline \multirow[t]{2}{*}{$\begin{array}{l}\operatorname{ARMA}(1,0)- \\
\operatorname{eGARCH}(2,1)\end{array}$} & \multirow[t]{2}{*}{$\begin{array}{l}\text { Skewed } \\
\text { Student } t\end{array}$} & $1 \%$ & 11.8 & 20 & $\begin{array}{l}\text { LR.uc Statistic: } \\
\text { LR.uc Critical: } \\
\text { LR.uc p-value: } \\
\text { Decision : }\end{array}$ & $\begin{array}{c}4.82 \\
6.635 \\
0.028 \\
\text { Accept } \\
\end{array}$ & $\begin{array}{l}\text { LR.cc Statistic: } \\
\text { LR.cc Critical: } \\
\text { LR.cc p-value: } \\
\text { Decision : }\end{array}$ & $\begin{array}{c}5.701 \\
9.21 \\
0.058 \\
\text { Accept } \\
\end{array}$ \\
\hline & & $5 \%$ & 58.8 & 76 & $\begin{array}{l}\text { LR.uc Statistic: } \\
\text { LR.uc Critical: } \\
\text { LR.uc p-value: } \\
\text { Decesion: }\end{array}$ & $\begin{array}{c}4.868 \\
3.841 \\
0.027 \\
\text { Reject }\end{array}$ & $\begin{array}{l}\text { LR.cc Statistic: } \\
\text { LR.cc Critical: } \\
\text { LR.cc p-value: } \\
\text { Decision: }\end{array}$ & $\begin{array}{c}5.048 \\
5.991 \\
0.08 \\
\text { Accept }\end{array}$ \\
\hline
\end{tabular}

Backtesting is a statistical technique that helps us to investigate whether the estimated GARCH is reliable or not. An estimated GARCH model is reliable if it is accepted that the model support correct exceedances. The table 12 above presents backtesting test for $\operatorname{ARMA}(1,0)$-eGARCH$(2,1)$ model obtained for daily crude oil futures. At 99\% Value-at-Risk, the model passed the backtesting test using the Unconditional and conditional coverage while 95\% Value-at-Risk the model failed using the unconditional coverage and passed using the conditional coverage. On the average the model is reliable.

Table 13: ARIMAX models for Weekly log stock prices and Returns

\begin{tabular}{|c|c|c|c|c|c|}
\hline $\begin{array}{l}\text { Variable/ } \\
\text { Model }\end{array}$ & $\begin{array}{l}\text { paramete } \\
\text { rs }\end{array}$ & Estimates & & & Diagnostics (Residual) \\
\hline $\begin{array}{l}\text { Lnprice } \\
\text { ARIMAX }(1,1 \\
, 0)\end{array}$ & $\begin{array}{l}\operatorname{ar1} \\
\operatorname{drift} \\
\operatorname{gfc} \\
\text { covid-19 }\end{array}$ & $\begin{array}{l}\text { Estimate } \\
0.0158169 \\
-0.0003560 \\
-0.0273024 \\
-0.0654602\end{array}$ & $\begin{array}{rr}\text { Std. Error } & \text { z value } \\
0.0308537 & 0.5126 \\
0.0016723 & -0.2129 \\
0.0378755 & -0.7208 \\
0.0535714 & -1.2219\end{array}$ & $\begin{array}{l}\operatorname{Pr}(>|z|) \\
0.6082 \\
0.8314 \\
0.4710 \\
0.2217\end{array}$ & $\begin{array}{l}\text { JB test: } p:<2.2 e-16 \\
\text { Box-Ljung test: } p=0.00092 \\
\text { ARCH LM-test, } p<2.2 e-16\end{array}$ \\
\hline $\begin{array}{l}\text { Returns } \\
\operatorname{ARIMAX}(1,0 \\
, 0)\end{array}$ & $\begin{array}{l}\operatorname{arl} \\
\text { constant } \\
\text { gfc } \\
\text { covid-19 }\end{array}$ & $\begin{array}{l}\text { Estimate } \\
-0.0206484 \\
0.0011061 \\
-0.0017085 \\
-0.0834801\end{array}$ & $\begin{array}{lr}\text { Std. Error z value } \\
0.0308047 & -0.6703 \\
0.0016928 & 0.6534 \\
0.0050542 & -0.3380 \\
0.0126200 & -6.6149\end{array}$ & $\begin{array}{c}\quad \operatorname{Pr}(>|z|) \\
0.5027 \\
0.5135 \\
0.7353 \\
3.717 e-11 \quad \star \star \star\end{array}$ & $\begin{array}{l}\text { JB test: } \mathrm{p}:<2.2 \mathrm{e}-16 \\
\text { Box-Ljung test: } \mathrm{p}=0.004771 \\
\text { ARCH LM-test, } \mathrm{p}<2.2 \mathrm{e}-16\end{array}$ \\
\hline
\end{tabular}

The Auto.arima function in R software was used to implement the best ARIMA model for the $\log$ stock price and returns as presented in table 13 above. For the log stock prices ARIMAX $(1,1,0)$ was optimal for the weekly crude oil futures and the autoregressive coefficient was not significant while the global financial crisis (gfc)and the impact of COVID-19 were 
negative but not significant. The model was not adequate while the residual is not normally distributed and exhibited Arch effects.

For the log returns $\operatorname{ARIMAX}(1,0)$ was optimal for the weekly crude oil futures returns and the autoregressive coefficient was not significant while the impact of global financial crisis (gfc) was negative and the impact of COVID-19 was positive but only COVID-19 effect was significant. The model was not adequate while the residual is not normally distributed and exhibited Arch effects.

Table 14: GARCH models and their performance on the log returns of weekly Crude Oil WTI Futures Historical log Stock returns

\begin{tabular}{|c|c|c|c|}
\hline Model & $\begin{array}{l}\text { Information } \\
\text { criteria }\end{array}$ & $\begin{array}{l}\text { Std } t \\
\text { innovation }\end{array}$ & $\begin{array}{l}\text { Skewed stdt } \\
\text { innovation }\end{array}$ \\
\hline $\begin{array}{l}\text { ARMA }(1,0)-\mathrm{s} \text { GARCH } \\
(1,1)\end{array}$ & $\begin{array}{l}\text { Akaike } \\
\text { Bayes } \\
\text { Shibata } \\
\text { Hannan-Quinn }\end{array}$ & $\begin{array}{l}-3.2902 \\
-3.2527 \\
-3.2903 \\
-3.2760\end{array}$ & $\begin{array}{l}-3.3103 \\
-3.2681 \\
-3.3104 \\
-3.2943\end{array}$ \\
\hline $\begin{array}{l}\operatorname{ARMA}(1,0)-\mathrm{s} G A R C H \\
(2,1)\end{array}$ & $\begin{array}{l}\text { Akaike } \\
\text { Bayes } \\
\text { Shibata } \\
\text { Hannan-Quinn }\end{array}$ & $\begin{array}{l}-3.2892 \\
-3.2470 \\
-3.2894 \\
-3.2732\end{array}$ & $\begin{array}{l}-3.3096 \\
-3.2627 \\
-3.3097 \\
-3.2918\end{array}$ \\
\hline $\begin{array}{l}\operatorname{ARMA}(1,0)- \\
\operatorname{sGARCH}(2,2)\end{array}$ & $\begin{array}{l}\text { Akaike } \\
\text { Bayes } \\
\text { Shibata } \\
\text { Hannan-Quinn }\end{array}$ & $\begin{array}{l}-3.2900 \\
-3.2431 \\
-3.2902 \\
-3.2722\end{array}$ & $\begin{array}{l}-3.3101 \\
-3.2586 \\
-3.3103 \\
-3.2906\end{array}$ \\
\hline $\begin{array}{l}\operatorname{ARMA}(1,0)- \\
\operatorname{eGARCH}(1,1)\end{array}$ & $\begin{array}{l}\text { Akaike } \\
\text { Bayes } \\
\text { Shibata } \\
\text { Hannan-Quinn }\end{array}$ & $\begin{array}{l}-2.0790 \\
-2.0369 \\
-2.0792 \\
-2.0631\end{array}$ & $\begin{array}{l}-2.0190 \\
-1.9722 \\
-2.0192 \\
-2.0013\end{array}$ \\
\hline $\begin{array}{l}\operatorname{ARMA}(1,0)- \\
\operatorname{eGARCH}(2,1)\end{array}$ & $\begin{array}{l}\text { Akaike } \\
\text { Bayes } \\
\text { Shibata } \\
\text { Hannan-Quinn }\end{array}$ & $\begin{array}{l}-3.2737 \\
-3.2222 \\
-3.2739 \\
-3.2542\end{array}$ & $\begin{array}{l}-3.3183 \\
-3.2621 \\
-3.3185 \\
-3.2970\end{array}$ \\
\hline $\begin{array}{l}\text { ARMA }(1,0)- \\
\text { eGARCH }(2,2)\end{array}$ & $\begin{array}{l}\text { Akaike } \\
\text { Bayes } \\
\text { Shibata } \\
\text { Hannan-Quinn }\end{array}$ & $\begin{array}{l}-3.3019 \\
-3.2457 \\
-3.3021 \\
-3.2806\end{array}$ & $\begin{array}{l}-3.3273 \\
-3.2664 \\
-3.3276 \\
-3.3042\end{array}$ \\
\hline
\end{tabular}




\begin{tabular}{|c|c|c|c|}
\hline $\begin{array}{l}\text { ARMA }(1,0)-\text { TGARCH } \\
(1,1)\end{array}$ & $\begin{array}{l}\text { Akaike } \\
\text { Bayes } \\
\text { Shibata } \\
\text { Hannan-Quinn }\end{array}$ & $\begin{array}{l}-3.3012 \\
-3.2591 \\
-3.3014 \\
-3.2853\end{array}$ & $\begin{array}{l}-3.3260 \\
-3.2792 \\
-3.3262 \\
-3.3083\end{array}$ \\
\hline $\begin{array}{l}\text { ARMA }(1,0)-\text { TGARCH } \\
(2,1)\end{array}$ & $\begin{array}{l}\text { Akaike } \\
\text { Bayes } \\
\text { Shibata } \\
\text { Hannan-Quinn }\end{array}$ & $\begin{array}{l}-3.2979 \\
-3.2464 \\
-3.2982 \\
-3.2784\end{array}$ & $\begin{array}{l}-3.3227 \\
-3.2665 \\
-3.3230 \\
-3.3014\end{array}$ \\
\hline $\begin{array}{l}\text { ARMA }(1,0)-\text { TGARCH } \\
(2,2)\end{array}$ & $\begin{array}{l}\text { Akaike } \\
\text { Bayes } \\
\text { Shibata } \\
\text { Hannan-Quinn }\end{array}$ & $\begin{array}{l}-3.2961 \\
-3.2398 \\
-3.2963 \\
-3.2748\end{array}$ & $\begin{array}{l}-3.3209 \\
-3.2600 \\
-3.3212 \\
-3.2978\end{array}$ \\
\hline $\begin{array}{l}\text { ARMA }(1,0)-\operatorname{apARCH} \\
(1,1)\end{array}$ & $\begin{array}{l}\text { Akaike } \\
\text { Bayes } \\
\text { Shibata } \\
\text { Hannan-Quinn }\end{array}$ & $\begin{array}{l}-3.3023 \\
-3.2554 \\
-3.3025 \\
-3.2845\end{array}$ & $\begin{array}{l}-3.3263 \\
-3.2748 \\
-3.3265 \\
-3.3068\end{array}$ \\
\hline $\begin{array}{l}\operatorname{ARMA}(1,0)-\operatorname{apARCH} \\
(2,1)\end{array}$ & $\begin{array}{l}\text { Akaike } \\
\text { Bayes } \\
\text { Shibata } \\
\text { Hannan-Quinn }\end{array}$ & $\begin{array}{l}-3.2985 \\
-3.2423 \\
-3.2988 \\
-3.2772\end{array}$ & $\begin{array}{l}-3.3228 \\
-3.2619 \\
-3.3231 \\
-3.2997\end{array}$ \\
\hline $\begin{array}{l}\text { ARMA }(1,0)-\operatorname{apARCH} \\
(2,2)\end{array}$ & $\begin{array}{l}\text { Akaike } \\
\text { Bayes } \\
\text { Shibata } \\
\text { Hannan-Quinn }\end{array}$ & $\begin{array}{l}-3.2975 \\
-3.2366 \\
-3.2978 \\
-3.2744\end{array}$ & $\begin{array}{l}-3.3219 \\
-3.2563 \\
-3.3222 \\
-3.2970\end{array}$ \\
\hline
\end{tabular}

The table 14 above presents the selection criteria values for weekly crude oil futures based on the student $\mathrm{t}$ and skewed student $\mathrm{t}$ distributions. The ARMA model favoured the ARMA(1,0) model while the competing GARCH models (that is sGARCH, eGARCH, TGARCH and apARCH) used a maximum lag of 2 . The selection criteria seems to be lowest for skewed student $t$ distribution compared to student $\mathrm{t}$ distribution except in few cases. This is so because the return series was negatively skewed. Among the competing ARMA-GARCH models, ARMA(1,0)eGARCH $(2,2)$ with skewed student $\mathrm{t}$ distribution had the least selection criteria values while $\operatorname{ARMA}(1,0)-e G A R C H(1,1)$ with student $t$ distribution. Hence $\operatorname{ARMA}(1,0)-e G A R C H(2,2)$ with skewed student $t$ distribution emerged as the superior model for weekly crude oil futures with the effects of global financial crisis and the present COVID-19 crisis. 
Table 15: Persistence and Half-life Volatility of the GARCH models of weekly Crude Oil WTI Futures Historical log Stock returns

\begin{tabular}{|c|c|c|c|c|}
\hline Models & \multicolumn{2}{|c|}{ Std } & \multicolumn{2}{|c|}{ Skewed std } \\
\hline & Persistence & $\begin{array}{l}\text { Half-life } \\
\text { volatility }\end{array}$ & Persistence & $\begin{array}{l}\text { Half-life } \\
\text { volatility }\end{array}$ \\
\hline $\operatorname{ARMA}(1,0)-\mathrm{sGARCH} \quad(1,1)$ & 0.9614409 & 17.62739 & 0.9668441 & 20.55718 \\
\hline $\operatorname{ARMA}(1,0)-\mathrm{sGARCH} \quad(2,1)$ & 0.9599364 & 16.95222 & 0.9651074 & 19.51654 \\
\hline $\operatorname{ARMA}(1,0)-\operatorname{sGARCH}(2,2)$ & 0.9322973 & 9.88748 & 0.9392686 & 11.06313 \\
\hline $\operatorname{ARMA}(1,0)-\mathrm{eGARCH}(1,1)$ & 0.9000715 & 6.58378 & 0.9000358 & 6.581296 \\
\hline $\operatorname{ARMA}(1,0)-\operatorname{eGARCH}(2,1)$ & 0.8647379 & 4.769511 & 0.9565334 & 15.59753 \\
\hline $\operatorname{ARMA}(1,0)-\operatorname{eGARCH}(2,2)$ & 0.9208541 & 8.406502 & 0.9263762 & 9.063727 \\
\hline $\operatorname{ARMA}(1,0)-\mathrm{TGARCH} \quad(1,1)$ & 0.9514492 & 13.92729 & 0.9570926 & 15.8054 \\
\hline $\operatorname{ARMA}(1,0)-\mathrm{TGARCH}(2,1)$ & 0.9776593 & 30.67826 & 0.9795214 & 33.49968 \\
\hline $\operatorname{ARMA}(1,0)-\mathrm{TGARCH} \quad(2,2)$ & 0.9776573 & 30.67555 & 0.9795182 & 33.49437 \\
\hline $\operatorname{ARMA}(1,0)-\operatorname{apARCH}(1,1)$ & 0.9426188 & 11.7297 & 0.9540498 & 14.73547 \\
\hline $\operatorname{ARMA}(1,0)-\operatorname{apARCH} \quad(2,1)$ & 0.9455846 & 12.38827 & 0.9563807 & 15.54167 \\
\hline ARMA $(1,0)$-apARCH $(2,2)$ & 0.9006649 & 6.625251 & 0.9121822 & 7.541128 \\
\hline
\end{tabular}

Table 15 presents the persistence and half-life values for the competing models with the student $t$ and skewed student $\mathrm{t}$ distributions. The entire ARMA-GARCH model exhibited very high persistence value except for $\operatorname{ARMA}(1,0)-\operatorname{eGARCH}(2,1)$ though less than 1 (one), this could be due to the impact of global financial crisis and the present COVID-19 pandemic, but the entire model exhibited stability. For the $\operatorname{ARMA}(1,0)-\operatorname{eGARCH}(2,2)$, the persistence value is 0.9263762 while it take about 10 weeks for mean-reverting to take place. 
Table 16: Backtesting of the ARMA(1,0)-eGARCH(2,2): GARCH Roll Forecast (Backtest Length: 762) for Weekly Crude Oil Futures

\begin{tabular}{|c|c|c|c|c|c|c|c|c|}
\hline Model & Distributions & Alpha & $\begin{array}{l}\text { Expected } \\
\text { Exceed }\end{array}$ & $\begin{array}{l}\text { Actual } \\
\text { VaR } \\
\text { Exceed }\end{array}$ & $\begin{array}{l}\text { Unconditiona } \\
\text { Coverage } \\
\mathrm{H}_{0} \text { : Correct } \\
\text { Exceedances }\end{array}$ & piec) & $\begin{array}{l}\text { Conditional } \\
\text { Coverage } \\
\text { (Christoffe } \\
\mathrm{H}_{0} \text { : Correct } \\
\text { Exceedances } \\
\text { independenc } \\
\text { Failure }\end{array}$ & $\begin{array}{l}\text { rsen) } \\
\text { and } \\
\text { of }\end{array}$ \\
\hline \multirow[t]{2}{*}{$\begin{array}{l}\operatorname{ARMA}(1,0)- \\
\operatorname{eGARCH}(2,2)\end{array}$} & \multirow[t]{2}{*}{$\begin{array}{l}\text { Skewed } \\
\text { Student } t\end{array}$} & $1 \%$ & 7.6 & 13 & $\begin{array}{l}\text { LR.uc Statistic: } \\
\text { LR.uc Critical: } \\
\text { LR.uc p-value: } \\
\text { Decision: }\end{array}$ & $\begin{array}{r}3.167 \\
6.635 \\
0.075 \\
\text { Accept }\end{array}$ & $\begin{array}{l}\text { LR.cc Statistic: } \\
\text { LR.cc Critical: } \\
\text { LR.cc p-value: } \\
\text { Decision: }\end{array}$ & $\begin{array}{c}8.926 \\
9.21 \\
0.012 \\
\text { Accept }\end{array}$ \\
\hline & & $5 \%$ & 38.1 & 35 & $\begin{array}{l}\text { LR.uc Statistic: } \\
\text { LR.uc Critical: } \\
\text { LR.uc p-value: } \\
\text { Decision: }\end{array}$ & $\begin{array}{c}0.273 \\
3.841 \\
0.602 \\
\text { Accept }\end{array}$ & $\begin{array}{l}\text { LR.cc Statistic: } \\
\text { LR.cc Critical: } \\
\text { LR.cc p-value: } \\
\text { Decision: }\end{array}$ & $\begin{array}{c}3.133 \\
5.991 \\
0.209 \\
\text { Accept }\end{array}$ \\
\hline
\end{tabular}

The table 16 above presents backtesting test for ARMA(1,0)-eGARCH(2,2) model obtained for weekly crude oil futures. At 99\% Value-at-Risk, the model passed the backtesting test using the Unconditional and conditional coverage while 95\% Value-at-Risk the model also passed using the unconditional coverage and passed using the conditional coverage. On the overall the estimated ARMA(1,0)-eGARCH(2,2) model is reliable.

\section{Discussion of Results}

The table 1 presents the descriptive statistics of the daily crude oil futures price from the $4^{\text {th }}$ January 2000 to $27^{\text {th }}$ April 2020. The maximum stock price for Crude oil futures was $\$ 145.2900$ that occurred during the global financial crisis and the minimum stock price for the crude oil futures was $\$ 10.01000$ which occurred during the COVID-19 crisis. The price had high standard deviation with positive skewness with a moderate kurtosis but the stock price was not normally distributed using Jarque-Bera (JB) statistic. The log stock price revealed an average of 4.022398, maximum value of 4.978730 , minimum value of 2.303580 with standard deviation of 0.456812 , having a negative skewness but have a similar value of kurtosis as the stock price of the crude oil futures and the log price series was not normally distributed. The log returns of crude oil futures exhibited a negative mean (-0.000134) which signifies a loss in stock returns over the period under consideration. In addition, 0.319640 was maximum returns, - -0.601680 was minimum returns with standard deviation of 0.027099 , but the returns exhibited negative skewness and very high kurtosis value of 63.80617 and finally, the returns series was not normally distributed 
and there is evidence of arch effects in the returns series. In most empirical analysis, oil stock returns are not always normally distributed and returns possessed high kurtosis (Chen, 2014).

Fig. 1 represents the time plot of the daily crude oil futures stock prices. The highest stock price occurred during the global financial crisis of mid 2007 and early 2009 but the least stock price occurred during the COVID-19 crisis which indicated that crude oil futures was worse hit by the COVID-19 pandemic.Fig. 2 represents the time plot of the daily crude oil futures stock prices and returns. The highest stock price occurred during the global financial crisis of mid 2007 and early 2009 but the least stock price occurred during the COVID-19 crisis which indicated that crude oil futures is was hit by the COVID-19 pandemic as shown in figure 1. In addition, high volatility occurred during 2008 and 2020 . This is supported by previous research, as during crisis either global financial crisis or COVID-19, stock prices and returns are highly volatile and characterized by losses and fears (Chen, 2014; Adenomon, et al. 2020, Yousef, 2020).

The table 2 above presents the descriptive statistics of the daily crude oil futures during the global financial crisis and COVID-19 crisis. During the global financial crisis price from $2^{\text {nd }}$ July 2007 to $31^{\text {st }}$ March 2009. During the global financial crisis, the mean price of crude oil futures was $\$ 87.08717$ with maximum stock price for Crude oil futures was $\$ 145.2900$ minimum stock price for the crude oil futures was $\$ 38.87$. The price had high standard deviation with negative skewness with a moderate kurtosis but the stock price was not normally distributed using JarqueBera (JB) statistic. The log stock price revealed an average of 4.401270, maximum value of 4.978730, minimum value of 3.522530 with standard deviation of 0.379896 , having a negative skewness but have a moderate value of kurtosis but log price of the crude oil futures was not normally distributed. The log returns of crude oil futures during the global financial crisis exhibited a negative mean (-0.000815) which signifies a loss in stock returns during the global financial crisis. In addition, 0.164100 was maximum returns, -0.130650 was minimum returns with standard deviation of 0.037183 , but the returns exhibited negative skewness and high kurtosis value of 5.766774 and finally, the returns series was not normally distributed and there is evidence of arch effects in the returns series. The characteristics of crude oil prices and stocks follow common stock prices characteristics, while in crisis period the volatility is very high similar to studies such as (Chen, 2014; Adenomon, et al. 2020, Yousef, 2020). 
The table 2 above further presents the descriptive statistics of the daily crude oil futures during the COVID-19 pandemic. During the COVID-19 crisis price from $1^{\text {st }}$ January 2020 to $27^{\text {th }}$ April 2020. During this present COVID-19 crisis, the mean price of crude oil futures was $\$ 41.24000$ with maximum stock price for Crude oil futures was $\$ 63.27000$, minimum stock price for the crude oil futures was $\$ 10.01000$. The price had high standard deviation with negative skewness with a low kurtosis but the stock price was not normally distributed using Jarque-Bera (JB) statistic. The log stock price revealed an average of 3.624131, maximum value of 4.147410, minimum value of 2.303580 with standard deviation of 0.468918 , having a negative skewness but have a moderate value of kurtosis but $\log$ price of the crude oil futures was not normally distributed. The log returns of crude oil futures during the global financial crisis exhibited a negative mean (-0.018896) which signifies a loss in stock returns during the present COVID-19 pandemic. In addition, 0.319640 was maximum returns, -0.601680 was minimum returns with standard deviation of 0.107638 , but the returns exhibited negative skewness and high kurtosis value of 13.93005 and finally, the returns series was not normally distributed and there was no evidence of arch effects in the returns series. This descriptive statistics is similar to (Chen, 2014; Adenomon, et al. 2020, Yousef, 2020).

Fig. 3 presents the time plot of the daily crude oil futures stock prices, the stock price got to its peak in 2008 and got to it least price in late 2008 during the global financial crisis.Fig. 4 presents the time plot of the daily crude oil futures stock prices and returns, the stock price got to its peak in 2008 and got to it least price in late 2008 during the global financial crisis. While the returns during the global financial crisis period exhibited high volatility during late 2008 to early 2009. Fig. 5 presents the time plot of the daily crude oil futures stock prices, the stock price shows almost steady decline in the crude oil futures during this present COVID-19 crisis. Fig. 6 presents the time plot of the daily crude oil futures stock prices and returns, the stock price and returns shows almost steady decline in the crude oil futures during this present COVID-19 crisis. Evidences from the figures during crisis revealed that crude oil futures could be affected negatively leading to losses in value of stock returns (Junttila and Raatikainen , 2018). 
The unit root testing was carried using ADF, DF-GLS and PP test on the daily crude oil stock prices and returns. In the table 3 above, the stock price of the crude oil for the full sample was not stationary but for the stock returns for the full sample was stationary. The unit root testing was carried using ADF, DF-GLS and PP test on the daily crude oil stock prices and returns during the global financial crisis and COVID-19 crisis. In the table 4 above, the stock returns of the crude oil for the Crisis periods (global financial crisis and COVID-19 crisis) was stationary. These results regarding stationarity of returns are expected as returns are mostly stationary (Adenomon et al. 2020).

The table 1 also presents the descriptive statistics of the weekly crude oil futures price from the $2^{\text {nd }}$ January 2000 to $26^{\text {th }}$ April 2020. The maximum stock price for Crude oil futures was $\$ 145.2900$ that occurred during the global financial crisis and the minimum stock price for the crude oil futures was $\$ 15.54000$ which occurred during the COVID-19 crisis. The price had high standard deviation with positive skewness with a moderate kurtosis but the stock price was not normally distributed using Jarque-Bera (JB) statistic. The log stock price revealed an average of 4.020047 , maximum value of 4.978732 , minimum value of 2.743417 with standard deviation of 0.459732 , having a negative skewness but have a similar value of kurtosis as the stock price of the crude oil futures and the log price series was not normally distributed. The log returns of crude oil futures exhibited a negative mean (-0.000419) which signifies a loss in stock returns over the period under consideration. In addition, 0.275756 was maximum returns, 0.346863 was minimum returns with standard deviation of 0.053635 , but the returns exhibited negative skewnessand high kurtosis value of 8.829281 and finally, the returns series was not normally distributed and there is evidence of arch effects in the returns series. The descriptive statistics here is similar to that obtain for daily crude oil futures the result

Fig. 7 represents the time plot of the weekly crude oil futures stock prices. The highest stock price occurred during the global financial crisis of mid 2007 and early 2009 but the least stock price occurred during the COVID-19 crisis which indicated that crude oil futures was worse hit by the COVID-19 pandemic. Fig. 8 represents the time plot of the daily crude oil futures stock prices and returns. The highest stock price occurred during 
the global financial crisis of mid 2007 and early 2009 but the least stock price occurred during the COVID-19 crisis which indicated that crude oil futures was worse hit by the COVID-19 pandemic as shown in figure 7 above. In addition, high volatility occurred during 2008 and 2020 (Yousef, 2020).

The table 6 above presents the descriptive statistics of the weekly crude oil futures during the global financial crisis and COVID-19 crisis. During the global financial crisis price from $1^{\text {st }}$ July 2007 to $29^{\text {th }}$ March 2009. During the global financial crisis, the mean price of crude oil futures was $\$ 86.88424$ with maximum stock price for Crude oil futures was $\$ 145.2900$ minimum stock price for the crude oil futures was $\$ 33.87000$. The price had high standard deviation with negative skewness with a moderate kurtosis but the stock price was normally distributed using Jarque-Bera (JB) statistic. The log stock price revealed an average of 4.397053, maximum value of 4.978732 , minimum value of 3.522530 with standard deviation of 0.386306 , having a negative skewness but have a moderate value of kurtosis but log price of the crude oil futures was not normally distributed. The log returns of crude oil futures during the global financial crisis exhibited a negative mean (-0.003230) which signifies a loss in stock returns during the global financial crisis. In addition, 0.241221 was maximum returns, -0.312180 was minimum returns with standard deviation of 0.082045 , but the returns exhibited negative skewness and high kurtosis value of 6.217034 and finally, the returns series was not normally distributed and there is evidence of arch effects in the returns series(Chen, 2014)..

The table 6 above further presents the descriptive statistics of the weekly crude oil futures during the COVID-19 pandemic. During the COVID-19 crisis price from $5^{\text {th }}$ January 2020 to $26^{\text {th }}$ April 2020. During this present COVID-19 crisis, the mean price of crude oil futures was $\$ 37.80235$ with maximum stock price for Crude oil futures was $\$ 59.04000$, minimum stock price for the crude oil futures was $\$ 15.54000$. The price had high standard deviation with negative skewness with a low kurtosis but the stock price was normally distributed using Jarque-Bera (JB) statistic. The log stock price revealed an average of 3.531572, maximum value of 4.078215 , minimum value of 2.743417 with standard deviation of 0.481373 , having a negative skewness but have a low value of kurtosis but log price of the crude oil futures was normally distributed. The $\log$ returns of crude oil futures during the present COVID-19 crisis exhibited a negative mean (- 
0.082383) which signifies a loss in stock returns during the present COVID-19 pandemic. In addition, 0.275756 was maximum returns, -0.346863 was minimum returns with standard deviation of 0.140145 , but the returns exhibited positive skewness and high kurtosis value of 4.055285 and finally, the returns series was normally distributed and there was no evidence of arch effects in the returns series(Chen, 2014).

Fig 9 above presents the time plot of weekly crude oil futures during the global financial crisis from $1^{\text {st }}$ July 2007 to $29^{\text {th }}$ March 2009. The crude reached its peak around 2008 but fell towards the end of 2008 and began to rise around early 2009.

Fig 10 presents the time plot of weekly crude oil futures log stock prices and returns.

The log stock prices and returns almost exhibited similar pattern during the global financial crisis as shown in fig. 9 above. Fig. 11 presents the time plot of the weekly crude oil futures stock prices from $5^{\text {th }}$ January 2020 to $26^{\text {th }}$ April 2020 during the COVID-19 Crisis, the stock price shows almost steady decline in the crude oil futures during this present COVID-19 crisis.Fig. 12 presents the time plot of the weekly crude oil futures stock prices and returns from $5^{\text {th }}$ January 2020 to $26^{\text {th }}$ April 2020 during the COVID-19 Crisis, the stock price shows almost steady decline in the crude oil futures during this present COVID-19 crisis. This is similar to the pattern in fig. 11 above. This shows that crude oil futures are more volatile during crisis Zavadska et al. (2020). The unit root testing was carried using ADF, DF-GLS and PP test on the weekly crude oil stock prices and returns. In the table 7 above, the stock price of the crude oil for the full sample was not stationary but for the stock returns for the full sample was stationary. The unit root testing was carried using ADF, DF-GLS and PP test on the weekly crude oil stock prices and returns during the global financial crisis and COVID-19 crisis. In the table 8 above, the stock returns of the crude oil for the Crisis periods (global financial crisis and COVID-19 crisis) were stationary. This is expected as returns are mostly stationary (Adenomon et al. 2020).

The univariate time series analysis and the univariate GARCH analysis of the daily and weekly stock prices and returns by including global financial crisis and COVID-19 crisis as dummy variables.The Auto.arima function in $\mathrm{R}$ software was used to implement the best ARIMA model for the log stock price and returns as presented in table 9 above. For the log stock prices $\operatorname{ARIMAX}(1,1,0)$ was optimal for the daily crude oil futures and the autoregressive coefficient 
was significant while the global financial crisis (gfc)and the impact of COVID-19 were positive but not significant. The model was not adequate while the residual is not normally distributed and exhibited Arch effects. For the log returns ARIMAX $(1,0)$ was optimal for the daily crude oil futures returns and the autoregressive coefficient was significant while the impact of global financial crisis (gfc) was negative and the impact of COVID-19 was positive but not significant. The model was not adequate while the residual is not normally distributed and exhibited Arch effects.

The Auto.arima function in R software was used to implement the best ARIMA model for the $\log$ stock price and returns as presented in table 13 above. For the log stock prices ARIMAX $(1,1,0)$ was optimal for the weekly crude oil futures and the autoregressive coefficient was not significant while the global financial crisis (gfc)and the impact of COVID-19 were negative but not significant. The model was not adequate while the residual is not normally distributed and exhibited Arch effects. For the log returns $\operatorname{ARIMAX}(1,0)$ was optimal for the weekly crude oil futures returns and the autoregressive coefficient was not significant while the impact of global financial crisis (gfc) was negative and the impact of COVID-19 was positive but only COVID-19 effect was significant. The model was not adequate while the residual is not normally distributed and exhibited Arch effects.

The above results from ARMA models for daily and weekly crude oil futures helped us to identify the order of the ARMA model but failed certain assumptions. Thus the need to fit ARMA-GARCH Models.

The table 10 above presents the selection criteria values for daily crude oil futures based on the student $t$ and skewed student $t$ distributions. The ARMA model favoured the ARMA $(1,0)$ model while the competing GARCH models (that is sGARCH, eGARCH, TGARCH and apARCH) used a maximum lag of 2 . The selection criteria seems to be lowest for skewed student $t$ distribution compared to student $t$ distribution except in few cases. This is so because the return series was negatively skewed. Among the competing ARMA-GARCH models, ARMA(1,0)eGARCH $(2,1)$ with skewed student $t$ distribution had the least selection criteria values while $\operatorname{ARMA}(1,0)-\mathrm{eGARCH}(2,2)$ with student $\mathrm{t}$ distribution. Hence $\operatorname{ARMA}(1,0)-\mathrm{eGARCH}(2,1)$ with skewed student $t$ distribution emerged as the superior model for daily crude oil futures with the 
effects of global financial crisis and the present COVID-19 crisis. This is in line with Wilhelmsson (2006).

Table 11 presents the persistence and half-life values for the competing models for daily crude oil futures with the student $t$ and skewed student $t$ distributions. The entire ARMA-GARCH model exhibited very high persistence value though less than 1 (one), this could be due to the impact of global financial crisis and the present COVID-19 pandemic Zavadska et al. (2020), but the entire model exhibited stability. For the $\operatorname{ARMA}(1,0)-\operatorname{eGARCH}(2,1)$, the persistence value is 0.9933146 while it take about 104 days for mean-reverting to take place.

The table 12 above presents backtesting test for $\operatorname{ARMA}(1,0)-\operatorname{eGARCH}(2,1)$ model obtained for daily crude oil futures. At $99 \%$ Value-at-Risk, the model passed the backtesting test using the Unconditional and conditional coverage while 95\% Value-at-Risk the model failed using the unconditional coverage and passed using the conditional coverage. On the average the model is reliable (Nieppola, 2009.

The table 14 above presents the selection criteria values for weekly crude oil futures based on the student $\mathrm{t}$ and skewed student $\mathrm{t}$ distributions. The ARMA model favoured the ARMA $(1,0)$ model while the competing GARCH models (that is sGARCH, eGARCH, TGARCH and apARCH) used a maximum lag of 2 . The selection criteria seems to be lowest for skewed student $t$ distribution compared to student $t$ distribution except in few cases. This is so because the return series was negatively skewed. Among the competing ARMA-GARCH models, ARMA(1,0)eGARCH(2,2) with skewed student $t$ distribution had the least selection criteria values while $\operatorname{ARMA}(1,0)-e G A R C H(1,1)$ with student $t$ distribution. Hence $\operatorname{ARMA}(1,0)-e G A R C H(2,2)$ with skewed student $t$ distribution emerged as the superior model for weekly crude oil futures with the effects of global financial crisis and the present COVID-19 crisis.This is in line with Wilhelmsson (2006).

Table 15 presents the persistence and half-life values for the competing models with the student $t$ and skewed student $\mathrm{t}$ distributions. The entire ARMA-GARCH model exhibited very high persistence value except for $\operatorname{ARMA}(1,0)-\operatorname{eGARCH}(2,1)$ though less than 1 (one), this could be due to the impact of global financial crisis and the present COVID-19 pandemicZavadska et al. 
(2020), but the entire model exhibited stability. For the $\operatorname{ARMA}(1,0)-\operatorname{eGARCH}(2,2)$, the persistence value is 0.9263762 while it take about 10 weeks for mean-reverting to take place. The table 16 above presents backtesting test for $\operatorname{ARMA}(1,0)-\operatorname{eGARCH}(2,2)$ model obtained for weekly crude oil futures. At $99 \%$ Value-at-Risk, the model passed the backtesting test using the Unconditional and conditional coverage while 95\% Value-at-Risk the model also passed using the unconditional coverage and passed using the conditional coverage. On the overall the estimated ARMA(1,0)-eGARCH(2,2) model is reliable (Nieppola, 2009).

Lastly the estimated ARMA(1,0)-eGARCH(2,1) and $\operatorname{ARMA}(1,0)-\operatorname{eGARCH}(2,2)$ for daily crude oil futures and weekly crude oil futures respectively have been significantly impacted by the global financial crisis and the Present COVID-19 pandemic Zavadska et al. (2020) while the preferred estimated models also passed the goodness-of-test fit.

\section{Conclusion and Recommendation}

This study investigates the impact of global financial crisis and the present COVID-19 pandemic on daily and weekly Crude oil futures using four variants of ARMA-GARCH models: ARMAsGARCH, ARMA-eGARCH, ARMA-TGARCH and ARMA-aPARCH with dummy variables .We also investigated the persistence, half-life and backtestingof the models. This study therefore seeks to contribute to the body of literature on the impact of global financial crisis and the present COVID-19 pandemic on crude oil futures market.This investigation of the impact of global financial crisis and the COVID-19 on crude oil futures has not been much studied at present. We obtained and analyzed the daily and weekly crude oil futures from secondary sources. The study used both student $t$ and skewed student $t$ innovations with AIC, goodness-oftest fit and backtesting to select the best model. Most of the estimated ARMA-GARCH models are supported by skewed student $t$ distribution while most of the ARMA-GARCH models exhibited high persistence values in the presence of global financial crisis and the COVID-19 pandemic.

In the overall, the estimated $\operatorname{ARMA}(1,0)-\operatorname{eGARCH}(2,1)$ and $\operatorname{ARMA}(1,0)-\mathrm{eGARCH}(2,2)$ model for daily crude oil futures and weekly crude oil futures respectively have been significantly impacted by the global financial crisis and the Present COVID-19 pandemic Zavadska et al. (2020) while the preferred estimated models also passed the goodness-of-test fit and backtesting.

This study recommends shareholders and investors should think outside the box as crude oil futures tends to be affected by global financial crisis and COVID-19 pandemic (Junttila and Raatikainen, 2018) 
Countries also that depend mostly on crude oil are encouraged to diversify their economy in other to survive and sustain during financial and health crisis.

\section{References}

Adekunle, W., Bagudo, AM., Odumosu, M., \&Inuolaji, SB (2020), "Predicting stock returns using crude oil prices: A firm level analysis of Nigeria's oil and gas sector" Resources Policy, Vol. 68. https://doi.org/10.1016/j.resourpol.2020.101708 Available online 4 May, 2020

Adenomon, MO.; Maijamaa, B. and John, DO. (2020) "On the Effects of COVID-19 outbreakon the Nigerian Stock exchange performance: Evidence from GARCH Models", doi:10.20944/preprints202004.0444.v1

Adrian, T. \&Natalucci, F (2020) "COVID-19 Crisis Poses Threat to Financial Stability" IMF Blog.https://blogs.imf.org. (Downloaded 4 May, 2020)

Ali G (2013) EGARCH, GJR-GARCH, TGARCH, AVGARCH, NGARCH, IGARCH, and APARCH Models for Pathogens at Marine Recreational Sites. Journal of Statistical and Econometric Methods, 2 (3): 57-73.

Arum, KC.,Uche, PI. (2017) "Volatility modeling using ARCH and GARCH models (A case study of the Nigerian Ctock Exchange). $1^{\text {st }}$ International Statistical Conference proceedings, Vol.1, September 6-8, 2017

Atoi NV (2014) Testing Volatility in Nigeria Stock Market Using Garch models. CBN Journal of Applied Statistics, 5: 65-93.

Bencivenga, C; D’Ecclesia, R. L. and Triuzi, U. (2012): Oil Prices and the Financial Crisis. Rev. Manag. Sci., 6:227-238.

Box, G. E.P. and Jenkins, G. M. (1970).Time Series Analysis, Forecasting and Control: San Francisco. Holden Day

Catani, PS \&Ahlgren, NJC (2017) "Combined Lagrange multiplier test for ARCH in vector autoregressive models", Econometrics and Statistic, Vol. 1: 62-84. https://doi.org/10.1016/j.ecosta.2016.10.006Get

Chen, C. Y-H. (2014): Does Fear Spill over? Asia-Pacific Journal of Financial Studies, 43:465491 
Chen, S., Min, W. \& Chen, R. (2013): Model Identification for Time Series with Dependent Innovation. StatisticaSinica, 23(2):873-899.

Christoffersen P, Jacobs K, Ornthanalai C, Wang Y (2008) Option valuation with long- run and short-run volatility components. Journal of Financial Economics 90, 272-297.

Dhamija A, Bhalla VK (2010) Financial time series forecasting: comparison of neural networks and ARCH models, International Research Journal of Finance and Management, 49 (1), 159-172

Ding Z, Granger CWJ, Engle RF (1993) A Long Memory Property Of Stock Market Returns And A New Model, Journal of Empirical Finance, 1, 83-106.

Emenogu, NG., Adenomon, MO., \&Nweze, NO. (2019) "Modeling and forecasting daily stock returns of Guaranty Trust bank PLC using ARMA-GARCH models, persistence, half-life volatility and backtesting" Science World Journal, 14 (3). Pp1-22.

Emenogu, NG.,Adenomon, MO., \&Nweze, NO. (2020) "On the volatility of daily stock returns of Total Nigeria Plc: evidence from GARCH models, value-at-risk and backtesting" Financial Innovation (2020) 6:18, https://doi.org/10.1186/s40854-020-00178-1, pp. 1-25.

Enders W (2004) Applied Econometric Time Series. John Wiley, New York.

Engle RF, Rangel J (2008) The spline-GARCH model for low-frequency volatility and its global macroeconomic causes. Review of Financial Studies 21, 1187-1222.

Enocksson D, Skoog J (2012) Evaluating VaR (Value-at-Risk): with the ARCH/GARCH class models via, European Union: Lambert Academic Publishing (LAP).

Francq, C. \&Zakoian, J-M. (2004): Maximum Likelihood Estimation of Pure GARCH and ARMA-GARCH Processes. Bernoulli, 10(4):605-637.

Grek A (2014) Forecasting accuracy for ARCH models and GARCH(1,1) family which model does best capture the volatility of the Swedish stock market? Statistics Advance Level Theses 15hp; Örebro University.

Hall P, Yao, P (2003) Inference in ARCH and GARCH Models with Heavy-Tailed Errors, Econometrica, 71, 285-317.

Interest Rates, and Output: Evidence from a Developing Economy” The Empirical Economics Letters, 5(4): 205-220.

Jiang W (2012) Using the GARCH model to analyse and predict the different stock markets" Master Thesis in Statistics, Department of Statistics, Uppsala University Sweden.

Jiang, Z-Q.and Zhou, W-X. (2014): Testing the weak-form efficiency of the WTI Crude oil futures Market. Physica A: Statistical Mechanics and Its applications, 405:235-244. 
Junttila, J. and Raatikainen, J. (2018): Commodity Market based Hedging against Stock market risk in times of financial crisis: The case of crude oil and gold. J. Intl Fin. Markets, Institutions and Money, 56:255-280.

Kang, S. H. and Yoon, S-M. (2017): Dynamic Spillover Effects among crude oil, precious metal, and agricultural commodity futures markets. Energy Economics, 62:19-32.

Kenton, W. reviewed by Scott, G. (2020), "Financial Crisis". https://www.investopedia.com/terms/f/financial-crisis.asp, updated March 16, 2020

Koul, H. L. \& Ling, S. (2006): Fitting an Error Distribution in Some Heteroscedastic Time Series Models. The Annals of Statistics, 34(2):994-1012.

Lange, T. (2011) "Tail behavior and OLS estimating in AR-GARCH models" StatisticaSinica, 21 (3): 1191-1200.

Ling, S. \&McAleer, M. (2003): On Adaptive Estimation in Non Stationary ARMA Models with GARCH Errors. The Annals of Statistics, 31(2):642-674.

Lioudis, N. (2020), "What Causes Oil Prices to Fluctuate?" Investopedia: https://www.investopedia.com/ask/answers/012715/what-causes-oil-prices-fluctuate.asp (visited 6 May, 2020)

Luo, J; Ji, Q; Klein, T; Todorova, N. and Zhang, D. (2020): On realized volatility of crude oil futures markets: forecasting with exogenous predictors under structural breaks. Energy Economics.https://doi.org/10.1016/j.eneco.2020.104781

Meitz, M. \&Saikkonen, P.(2011): Parameter Estimation in Non Linear AR-GARCH Models. Econometric Theory, 27(6):1236-1278.

Moshiri, S. \&Foroutan, F.(2006): Forecasting Non Linear Crude Oil Futures Prices. The Energy Journal, 27(4):81-95

Nelson D (1991) Conditional heteroskedasticity in asset pricing: A new approach. Econometrica 59, 347-370.

Nieppola, O.(2009): Backtesting Value-at-Risk Models. M.Sc. Thesis, Helsinki School of Economics, Finland.

of Total Nigeria Plc: evidence from GARCH models, value-at-risk and backtesting" Financial Innovation (2020) 6:18, https://doi.org/10.1186/s40854-020-00178-1, pp. 1-25.

Panait, I. \&Slavescu, EO. (2012) "Using GARCH-in-Mean Model to investigate volatility and persistence at different frequencies for Bucharest Stock Market during 1997-2012". Theoretical and Applied Economics, 19(5): 55-76.

Reserve Bank of Australia (2020): The Global Financial Crisis. www.rba.gov.au 
Rossi E (2004) Lecture notes on GARCH models. University of Pavia, March.

Ruppert, D.(2011) Statistics and Data Analysis for Financial Engineering. New York: Springer Science + Business Media

Sari, R. \&Soytas, U. (2006) “The Relationship between Stock Returns, Crude Oil Prices,

Singh, A. and Singh, N. P.(2017): Crude oil Market and Global Financial Crisis-Structural Break and Market Volatility Analaysis. Intl J. Econs. \& Bus. Res, 13(2):203-216 https://doi.org/10.1504/IJEBR.2017.082274

Sjölander, P. (2011) “A Stationary Unbiased Finite Sample ARCH-LM Test Procedure”, Applied Economics, 43(8): 1019-1033.

Tsay RS (2005) Analysis of Financial Time Series, 2nd Edition. New Jersey: John Wiley \& Sons.

Ulusoy V, Ozdurak C (2018) "The impact of oil Price volatility and gas company stock returns and emerging economies". Int J Energy Policy 8(1):144-158.

Wei, Y. and Wei, G. (2019): Oil Price fluctuation, stock market and macroeconomic fundamentals. Evidence from China before and after the financial crisis. Finance Research letters, 30:23-29 https://doi.org/10.1016/j.frl.2019.03.028

WHO (2020) “Coronavirus disease (COVID-19): Situation Report- 120”, 19 May, 2020

Wikipedia (2020) https://en.wikipedia.org/wiki/COVID-19_pandemic, (visited 4 May, 2020)

Wilhelmsson, A. (2006): GARCH Forecasting Performance under Different Distribution Assumptions. Journal of Forecasting, 25:561-578.

Yousef, I. (2020): The Impact of Coronavirus on Stock Market Volatility. https://www.researchgate.net/publication/341134119.

Zavadska, M; Morales, L. \& Coughlan, J. (2020): Brent Crude oil Prices Volatility during major Crisis. Financa Research Letters, 32.https://doi.org/10.1016/j.frl.2018.12.026

Zhang, Y-J.and Wang, Z-Y. (2013): Investigating the price discovery and risk transfer functions in the crude oil and gasoline futures markets: some empirical evidence. Applied Energy, 104:220-228. 
Zhu, K. \& Ling, S.(2011): Global Self-Weighted and Local Quasi-Maximum Exponential Likelihood Estimators for ARMA-GARCH/IGARCH Models. The Annals of Statistics, 39(4): 2131-2163. 